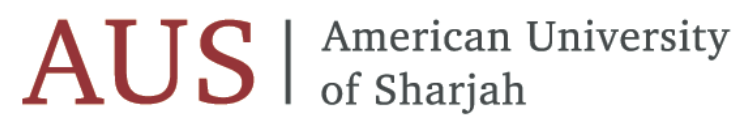

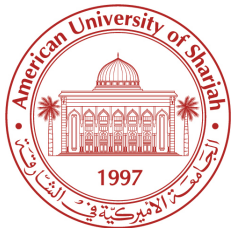

SCHOOL OF BUSINESS AND MANAGEMENT WORKING PAPER SERIES

SBMWPS: 16-01/2014

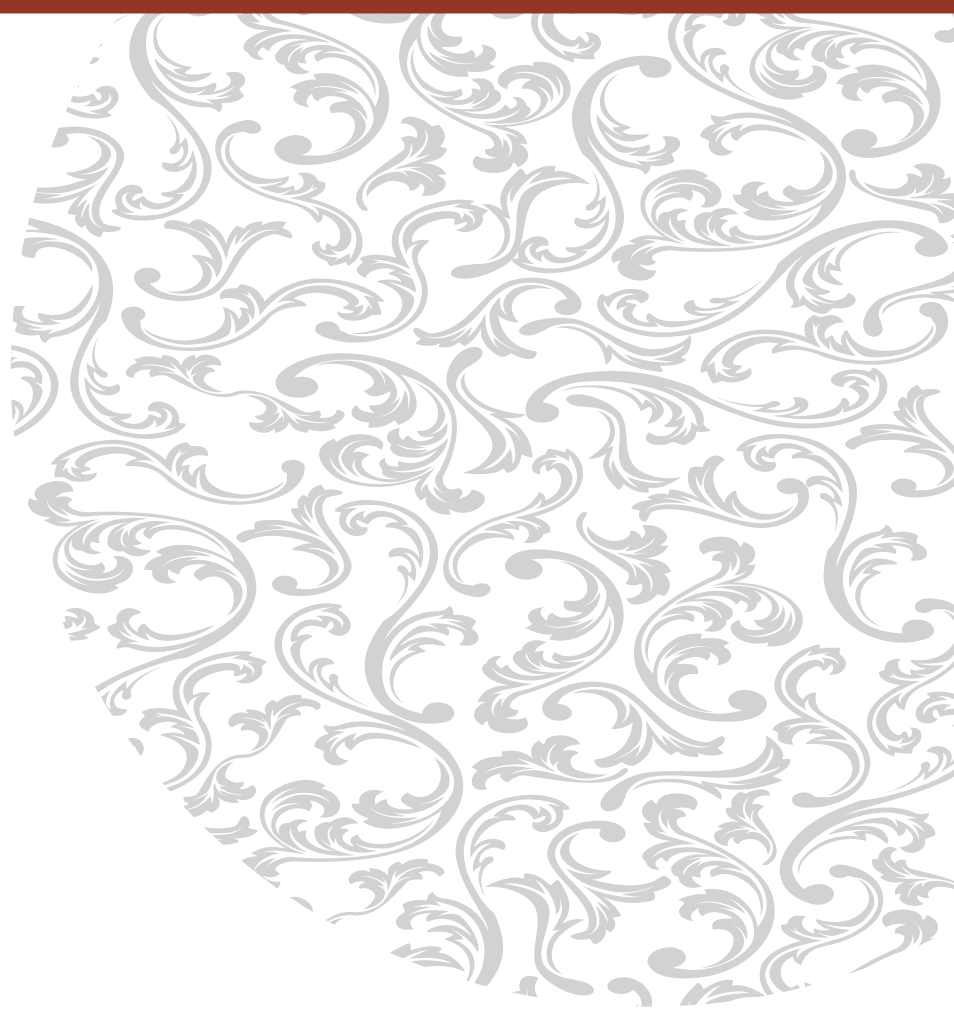

The RMB Debate: Empirical

Analysis on the Effects of

Exchange Rate Shocks in China and Japan

Soyoung Kim

Yoonbai Kim 
Working Paper 16-01/2014

School of Business \& Management

Working Paper Series (SBM WPS)

\section{The RMB Debate: Empirical Analysis on the Effects of Exchange Rate Shocks in China and Japan}

\section{Soyoung Kim}

Seoul National University

\section{Yoonbai Kim}

American University of Sharjah

University of Kentucky

The views expressed in papers published in our series are those of the author(s) and do not necessarily represent those of any department at SBM, the SBM itself, the American University of Sharjah (AUS) and/or any of their affiliates. Additionally, all papers in the series are made available on an "as is" basis without warranties of any kind. We, that is, the relevant department at SBM, SBM, AUS and/or any of the affiliates, hereby expressly disclaim any warranties of any kind, whether expressed or implied, including without limitation, the warranties of noninfringement, merchantability, and fitness for a particular purpose. Furthermore, we offer no warranties, expressed or implied, regarding the accuracy, sufficiency or suitability of the material found in the published papers. The users have the sole responsibility for inspecting and testing all content to their satisfaction before using them. 


\section{The RMB Debate: Empirical Analysis on the Effects of Exchange Rate Shocks in China and Japan ${ }^{+}$}

\author{
Soyoung Kim* \\ Seoul National University
}

\author{
Yoonbai Kim** \\ American University of Sharjah \\ and University of Kentucky
}

\footnotetext{
${ }^{+}$We wish to thank David Cook, He Dong, Wei Liao, and seminar participants at the AEA meetings, HKIMR, HKUST, and Beijing Forum for the various suggestions and comments they have given.

* Department of Economics, Seoul National University, Gwanak-Gu, Seoul 151-746, Republic of Korea, (PH) +822-880-2689; (Email) soyoungkim@snu.ac.kr.

${ }^{* *}$ Department of Economics, American University of Sharjah, PO Box 26666, Sharjah, United Arab Emirates. (PH) +971-6-515-4624, (FAX) +971-6-515-2550; (Email) ykim@aus.edu
} 


\begin{abstract}
For a better understanding of the ongoing debates on the RMB, this paper investigates the effects of exchange rate shocks on output and the current account for China and Japan. We use structural vector auto-regression models and find that yen appreciation reduces current account surpluses while having no strong effect on output in Japan. RMB appreciation, on the other hand, has insignificant effect on the current account, although it tends to reduce output in China. For China, dollar pricing with vertical trade integration seems responsible for the insignificant effect on the current account.
\end{abstract}

Keywords: renminbi appreciation, current account imbalance, VAR, exchange rate shocks, recession 


\section{Introduction}

The exchange value of China's currency, the renminbi (RMB), has become a contentious issue. Many economists argue that the currency is undervalued; thus, it has become the main source of the country's large current account surpluses especially in relation to the U.S. There has been mounting external pressure on China to allow the RMB to appreciate against the U.S. dollar. Many economists also argue that the exchange rate regime in China should change to market-based floating from heavy intervention in the foreign exchange market. ${ }^{1}$

Thus far, China has been resisting the pressure, permitting only gradual and small changes in its exchange rate policy. Apparently, its main concern seems to be that currency appreciation would cause detrimental effects on its crucial export sector and create a host of economic problems that may worsen the unemployment problem in the rural sector and reduce economic growth. The Japanese experience of undergoing a decades-long recession after huge appreciation has frequently been invoked as a reason for the resistance. In addition, some studies argue that exchange rate adjustments cannot restore the balance because the imbalances originate from structural problems, such as high consumption (and low savings) of the U.S. ${ }^{2}$ The heated contention between the two largest economies in the world has pushed the world economy into a situation of competitive devaluations or “currency wars” among many developed and emerging market economies.

In this paper, we briefly review two of the most contentious issues regarding the RMB. One is whether China should move to a float or at least an exchange rate regime with greater flexibility; the other is whether and how much the RMB is undervalued. We find irreconcilable differences around the two issues of the RMB debate. Important questions underlying the contentions are about (i) whether RMB appreciation can reduce trade imbalances in China and the U.S., and (ii) whether the appreciation can induce recessionary impacts on the Chinese economy. Admittedly, both are empirical issues. However, to our surprise, very few studies provide comprehensive empirical evidence on the issue.

The purpose of this paper is to examine empirically the effects of exchange rate changes on various macro variables of the Chinese economy, especially output and the current account/trade balance and their components. The studies of Ahmed (2009) and Thorbecke and Smith (2010)

\footnotetext{
${ }^{1}$ See, inter alia, Goldstein (2006), Roubini (2007) and Frankel (2006).

${ }^{2}$ See Bosworth (2004), McKinnon (2007), Mundell (2004), Tatom (2007), and Xu (2000).
} 
empirically examine the effects of (real) exchange rate changes on Chinese exports. Cheung, Chinn, and Fujii (2010), Kwack et al. (2007), Marquez and Schindler (2007), and Garcia-Herrero and Koivu (2007) estimate price elasticity of Chinese trade, exports and/or imports. Liao, Shi, and Zhang (2010) analyze the effects of exchange rate shocks from East Asian countries on Chinese exports using the calibrated Dynamic Stochastic General Equilibrium (DSGE) model. Shi (2006) examines the effects of real exchange rate changes on output in China using VAR model. Compared with these previous studies that frequently focus on a specific aspect of Chinese trade or output relation, the current study offers a comprehensive analysis of the $\mathrm{RMB} /$ dollar exchange rate changes on the Chinese economy. In addition, while most of the abovementioned studies analyze the relation with the real exchange rate, we examine the effects of nominal exchange rate changes because the effect of nominal exchange rate changes is more directly related to the current policy debate. Also, we examine the effects of the bilateral exchange rate against the U.S. dollar considering the recent policy debate between the U.S. and China. Then, as the Japanese experience is frequently invoked as supporting evidence, we apply a similar model to Japan and compare the results with those of China.

Analysis based on simple correlation among the current account, output, and the exchange rate can be misleading because many different structural shocks can affect these variables simultaneously. More importantly, the exchange rate, as an endogenous variable, not only affects but is also affected by output and the current account. In this paper, we employ a vector autoregression (VAR) model to take care of the third factor effects and the reverse causality problem and to isolate the exogenous part of exchange rate changes.

The rest of this paper is organized as follows. Section 2 briefly reviews the literature on the two main issues involving the RMB exchange rate and summarizes various channels on the effects of exchange rate changes on current account and output. Section 3 presents the empirical model to investigate the effects of exchange rate changes on current account and output in a unified manner. Section 4 documents empirical results. Section 5 explores further extensions of empirical analysis built on the baseline model. Section 6 concludes with summary and implications. 


\section{Literature Review}

Regarding the exchange rate of the RMB, two questions surface most frequently. One is whether or not China would be better off with a floating exchange rate. The other is whether it is undervalued and to what extent. We review the two issues first. Then, we briefly review various theories on the effects of exchange rate changes on current account and output in order to provide some theoretical background on our empirical analysis.

\subsection{Should China Float the RMB?}

Many economists argue that China should allow its currency to appreciate significantly and move to a regime of more flexible exchange rate. According to Roubini (2007), for instance, the RMB is grossly undervalued and it is in China's interest to move to a more flexible exchange rate regime. A failure to allow a nominal appreciation poses significant risks and potential costs, such as protectionist backlashes from the US and Europe and increasingly costly forex intervention. He further offers several reasons for doing so including: (i) protectionist backlashes from the US and Europe such as branding China as a “currency manipulator" by the U.S. Treasury or protectionist legislation such as the Schumer-Graham proposal of a $27.5 \%$ tariff on Chinese goods; (ii) forex intervention becomes increasingly costly due to the interest cost (with sterilization) or excessive liquidity credit and asset bubbles (without sterilization); (iii) "the imbalanced composition of aggregate demand” leading to excessive reliance on net exports and investment and a very low level of consumption;” (iv) greater capital losses on holdings of foreign reserves when the RMB appreciates; and (v) the risk of a surge in inflation. As the logic goes, it will free up the monetary policy from maintaining the exchange rate at a target level. The resulting appreciation of the RMB would reduce the inflationary pressure in China. More importantly, the appreciation will reduce the current account surpluses. He also argues that risks of an RMB appreciation, such as a slowdown of growth, worsening unemployment problems in the rural sector and deflationary pressures, would be modest and that their costs can be reduced through appropriate policies. ${ }^{3}$

\footnotetext{
${ }^{3}$ Frankel (2006) also offers five reasons to believe that it is in China’s interest to allow greater flexibility of the RMB. They are (i) overheating of the economy; (ii) excessive reserve accumulation; (iii) long-run need to use the exchange rate for expenditure-switching; (iv) avoiding future crashes; (v) low price level by international standards.
} 
The notion that a flexible exchange-rate regime would facilitate faster current account adjustment is, in fact, not well supported by empirical evidence. Chinn and Wei (2008) call such maintained hypothesis without firm empirical evidence "a faith-base initiative." They also show that the real exchange rate adjustment is not systematically related to how flexible a country's nominal exchange rate regime is. It suggests that there will be no guarantee that the RMB will appreciate under a flexible regime. ${ }^{4}$ The virtue of a flexible exchange rate regime in enhancing the effectiveness of China's macroeconomic policy may also be overrated. McKinnon (2007) disputes important elements of arguments proposed by pro-floaters as "Three Misconceptions" regarding exchange rate stabilization: (MC1) the exchange rate can affect the trade balance; (MC2) exchange rate appreciation reduces inflation; and (MC3) floating the rate would equilibrate the foreign exchange market. McKinnon also maintains that a current account surplus is the result of national saving being greater than investment and that the exchange rate has little to do with it. According to him, although the beneficial effect of currency appreciation on domestic inflation can be true in the long run, the short-run loss of monetary control can outweigh the deflationary impact of a higher exchange rate. Further, exchange rate floating would expose Chinese banks to excess exchange risk due to their immature creditor status. Drawing from the experience of Japan, he argues that currency appreciation - by creating asset bubbles and their bursting - could trigger a deflation in China similar to the one that dogged Japan for most of the 1990s and in the early 2000s. Instead of exchange rate adjustment, McKinnon argues that global rebalancing can be done via "expenditure reduction” policies.

\subsection{Is the RMB Undervalued and By How Much?}

Those who argue that the RMB is undervalued usually point to the following as evidence: (i) the current account is in large surpluses; (ii) foreign exchange reserves are huge and accumulating fast; (iii) the reserve accumulation is driven by hot money inflows as well as current account surpluses and inflows of FDI (hot money is flowing into China in expectation of

\footnotetext{
${ }^{4}$ For instance, the market actually expected RMB depreciation until October 2003, as measured by the nondeliverable forward rate.
} 
an RMB appreciation driven by massive trade surpluses and FDI flows); and (iv) without forex interventions, the RMB would have sharply appreciated. ${ }^{5}$

Various methods have been employed to rigorously assess the extent of exchange rate adjustment for the RMB. GAO (2005) and Cline and Williamson (2008) present a survey of related literature. Most popular ones employ some variations of purchasing power parity (PPP) and fundamental equilibrium exchange rate (FEER). According to the absolute version of PPP, equilibrium exchange rate is related to the ratio of price levels between two countries given by:

$\tilde{S}_{t}=P_{t}^{*} / P_{t}$, where $\tilde{S}_{t}$ is the equilibrium nominal exchange rate (also called the PPP rate) and $P_{t}$ and $P_{t}^{*}$ are the domestic and foreign price levels. (The nominal exchange rate is defined as the price of domestic currency in terms of foreign currency. Thus, an increase is appreciation of the domestic currency.) In one of the most popular examples of such an approach, the Economist magazine compiles the PPP rates based on the prices of Big Macs around the world. In a recent report published July 2010 (2013), the RMB was 47 (43) \% undervalued.

An extended version of PPP considers the tendency that the relative price of non-traded goods tends to be higher in high-income countries. According to the Balassa-Samuelson hypothesis, the tendency is due to the phenomenon that productivity differential is greater in traded goods than in non-traded goods because economic growth is more likely concentrated in productivity growth of such sectors as manufacturing classified as traded goods sector. On the other hand, with the extended PPP approach, Frankel (2009) estimates that the RMB is undervalued by $36 \%$ in 2000.

Another popular line of estimating the equilibrium is the fundamental equilibrium exchange rate (FEER), which is also called the macroeconomic balance approach. According to this approach, the equilibrium real exchange rate is the one that solves both internal and external balance. Internal balance is usually defined as full employment with price stability. External balance is more controversial but is defined as the current account balance close to zero or longterm sustainable capital flows. The macroeconomic balance approach generally involves assessing the change in the real effective exchange rate needed to close the gap between the

\footnotetext{
${ }^{5}$ On the other hand, those who dispute the undervaluation arguments maintain that US current account deficits and China's surpluses are structural and are induced by such factors as large fiscal deficits in the US and high Chinese savings rate. The latter is due to funding needs for education and health care, the absence of a sound social security system and social safety network, and underdeveloped credit market.
} 
actual or "underlying” current account balance of a country and its “equilibrium” level. This approach comprises three steps: (i) estimating the underlying current account balance; (ii) estimating the equilibrium current account balance; and (iii) estimating a trade model to calculate the exchange rate adjustment required to close the gap between the underlying and equilibrium current account balance, with key parameters being the price elasticities estimated for exports and imports (Dunaway, Leigh, and Lee, 2009). Employing the FEER approach, Cline and Williamson (2010) estimate that the RMB is 32.8\% undervalued as of March 2009, while Goldstein and Lardy (2009) come up with a smaller estimate of 20\%-25 \% as of the end of 2008. Table 1 presents a brief summary of estimates of RMB under- or over-valuation. ${ }^{6}$

Although most of the measures summarized in Table 1 point to the direction of RMB undervaluation, huge discrepancies on the magnitude of undervaluation exist and there does not seem to be an unambiguously clear choice for the best way by which to measure currency misalignment. Different criteria relate to different models. "The large variance in the estimates for equilibrium real exchange rates raises serious questions about the robustness of the results. The basic conclusion is that, at least for China, small changes in model specifications, explanatory variable definitions, and time period used in estimation can lead to very substantial differences in equilibrium real exchange rate estimates. Therefore, such estimates should be treated with great caution” (Dunaway, Leigh, and Lee, 2009). Given the host of uncertainties in determining key parameters of the model, such as the cyclical position of the economy and lagged effects of past exchange rate movements, the stance of fiscal and monetary policy, and current account "norm" or "structural capital flows," it is no wonder that we have such a bewildering array of estimates for RMB valuation. Thus, admittedly, while we cannot reject the no-misalignment null, we also cannot reject the $20 \%$ undervaluation null hypothesis at conventional significance levels. (Cheung, Chinn and Fujii, 2009)

\subsection{Effects of Exchange Rate Changes on Current Account and Output}

\footnotetext{
${ }^{6} \mathrm{We}$ omit the estimates based on another popular methodology called the behavioral equilibrium exchange rate (BEER). These models incorporate a variety of channels through which the real exchange can be related to other macroeconomic variables. Given that each author selects different variables to include, the implied misalignments will necessarily vary (Cheung, Chinn, and Fujii, 2009; Cline and Williamson, 2008; and Dunaway, Leigh, and Li., 2009).
} 
In this section, we briefly review the theories and arguments on the effects of exchange rate changes on the current account/trade balance and output, especially in the context of the Chinese economy. Regarding the effects on the current account, traditional open economy macro models, such as the Mundell-Fleming-Dornbusch model and the basic New Open Economy model (e.g., Obstfeld and Rogoff, 1995), incorporate the "expenditure switching" effect at the center of international transmission mechanism. These models typically assume producer currency pricing, in which prices of exports and imports are set in terms of producer's (or exporting country's) currency. For example, Chinese exports are set in terms of the RMB, while Chinese imports from the U.S. are set in terms of the U.S. dollars. In this case, an appreciation of the RMB increases one for one the export price in the U.S. dollar term and decreases the import price in the RMB term in a "complete pass-through" which, in turn, decreases foreign export demand but increases domestic import demand. This volume effect results in the worsening of the trade balance after a currency appreciation. However, the value effect on imports can lead to an increase in the trade balance as China's imports in the RMB term decline in the short run, given that the price of imports in the RMB term decreases.

Some recent studies suggest that prices of exports and imports may be set in terms of the importing country's currency. This is because maintaining a stable price from the importing country's perspective is important in keeping the customers. If the prices of both exports and imports are set in terms of the importing country's currency, as in the case of local currency pricing of Betts and Devereux (2000), the volume effect does not show up. For instance, as Chinese exports to the U.S. are set in U.S. dollars, an RMB appreciation does not affect the dollar prices of Chinese exports. This leads to a "no pass-through" scenario and, consequently, the U.S. demand for them does not change. Similarly, for China's imports, an RMB appreciation does not affect their RMB price in China and thus import demand is not affected. Exports in the RMB term will decline as the export price in the RMB term decreases with an RMB appreciation. The value effect decreases the trade balance in the RMB term.

In the intermediate case, in which exchange rate pass-through is partial or incomplete, the effects would be between the case of local currency pricing and the case of producer currency pricing. The volume effect that decreases the export quantity and increases the import quantity will partially appear. At the same time, the value effect that decreases exports and increase imports in local currency will also partially show up. 
Finally, both exports and imports of the emerging countries can be set in terms of an international currency, such as the U.S. dollar. Cook and Devereux (2006) analyze such a case in a theoretical model called "external currency pricing.” If both exports and imports of China are set in U.S. dollars, there will be no volume effect on exports to the U.S., considering that the export price in dollars does not change when the RMB appreciates; however, there will be a value effect on export in the RMB term as in the case of local currency pricing. The value effect will also appear in imports of China in the RMB term as in the case of producer currency pricing. These value effects decrease both exports and imports in the RMB term. Then, the quantity of imports increases (the volume effect) as the import price, which is in terms of the RMB, declines when the RMB appreciates.

Table 2 summarizes the implications of producer currency pricing, local currency pricing, an intermediate case, and dollar pricing (or external currency pricing) on Chinese exports and imports when RMB appreciates. From the second to the fifth columns, the theoretical effect of RMB appreciation on export and import prices in terms of RMB and U.S. dollars are summarized for each case. From the sixth to the ninth columns, the volume and the value effects on exports and imports are summarized for each case. Note that the value and the volume effects are for China's exports and imports in RMB terms. Thus, the direction of the value effect is the same as that of the RMB price. The direction of the volume effect on exports is opposite to that of export price in terms of US dollars because demand for Chinese exports in the U.S. market negatively depends on the dollar price of exports; on the other hand, the direction of the volume effect on imports is opposite to that of import price in terms of RMB because demand for Chinese imports negatively depends on the RMB price of imports.

Some researchers attribute the small or no effect of exchange rate changes on China's trade balance to the vertically integrated trade in East Asia. For example, Kim, Lee, and Park (2011) document that China has played a critical role in East Asia's vertical production integration as an assembly center of the production sharing networks. With China importing intermediate goods from the rest of East Asia and exporting the final assembled products to destinations outside the region, the rise of intra-Asian trade has been structurally dependent on extraregional demand. Koopman, Wang, and Wei (2008) show that the network is particularly dominant in electronic products, while Liao, Shi, and Zhang (2010) analyze China’s export dynamics with vertical trade. In the presence of vertical integration, the quantity of Chinese imports heavily depends on the 
quantity of Chinese exports, leading to small price elasticities of import demand and weak volume effects on Chinese imports.

Regarding the effects of exchange rate changes on output, traditional theory presupposes that output declines under appreciation (or revaluation) via the expenditure switching effect. If currency appreciation originates from a decline in liquidity, such as monetary contraction, the usual closed economy monetary transmission mechanism, including a decline in investment demand, may operate in a country with strict capital controls such as China. Past studies also document that changes in the exchange rate may work in the opposite direction, especially in the context of devaluation. In the monetary model, devaluation reduces aggregate demand by raising the domestic price level through higher prices of imported goods, thereby lowering real money balance (Frenkel and Johnson, 1976). The trade balance may worsen if the price elasticities of export and import demands are too low or if the initial trade balance is in deep deficit. DiazAlejandro (1963), Cooper (1971), and Krugman and Taylor (1978) all suggest various channels that can render devaluation to be contractionary. One such channel that has been theorized in Krugman and Taylor (1978) is a redistribution of income from low saving groups (wages) to high saving groups (profits). More recent studies focus on countries with open capital markets where currency depreciation may induce capital outflows, which have negative effects on the economy, for example, by reducing domestic liquidity. ${ }^{7}$ In the case of currency appreciation (or revaluation), all these channels would contribute to output expansion.

The supply-side channel can also be a source of the opposite effect on output. Currency appreciation may decrease the price of imported intermediate goods which, under indexation, wages, may result in a downward shift in the aggregate supply (Findlay and Rodriguez, 1977; Sachs, 1980; Marston, 1982; and Buffie, 1989). With the liberalization of the financial markets, additional channels have emerged, especially in developing countries. When domestic financial and nonfinancial firms have liabilities in foreign currency, currency appreciation can decrease debt-serving obligation, thereby working as a positive supply shock (Gylfason and Risager, 1984; Cespeds, Chang and Velasco, 2004).

\footnotetext{
${ }^{7}$ See Kim and Yang (2011) for empirical evidence on the effects of capital inflows on East Asian economies.
} 


\section{The Model and Empirical Evidence}

Key reasons for controversies around the extent of RMB undervaluation and the appropriate exchange rate regime are (i) skepticism about the role of exchange rate changes in the process of external adjustment, and (ii) the fear that the suggested appreciation of the RMB may induce a Japan-style long-term stagnation in China. In this section, we attempt to offer an assessment to these questions using structural VAR models. We first analyze the issue based on a relatively small basic VAR model, after which we consider various extensions to check the detailed transmission and the robustness of the results.

We consider a VAR model that includes the following endogenous variables: the capital account as a ratio to the trend GDP (KAR), real GDP (RY), the price level (P), real money supply (RM), the current account as a ratio to the trend GDP (CAR), and the nominal exchange rate against the U.S. dollar (NX). To construct the trend GDP, we use the fitted value of GDP obtained from a regression of the nominal GDP to a linear trend. ${ }^{8}$ The real money supply (RM) is calculated by dividing the money supply (M1) by the consumer price index. The consumer price index is used as the price level. Note that nominal exchange rate is defined as U.S. dollars per RMB or yen. Therefore, an increase in nominal exchange rate results in the appreciation of the RMB or yen.

The model also includes three measures of external variables to control for exogenous shocks: the foreign interest rate (RF), foreign real income (RYF), and foreign price level (PF). The U.S. real GDP is used as foreign output (RYF), the U.S. three-month Treasury bill rate is used as the foreign interest rate, and consumer price index is used as foreign price level (PF). All variables are in logarithm (multiplied by 100) except for the interest rate and the capital- and the current account ratios (multiplied by 100).

These variables are included to eliminate the effects of third factors that may generate spurious correlation between exchange rate and the variables of interests, such as, output and the current account. For example, a sharp increase in capital inflows may lead to an economic boom, a current account deficit, and nominal and real exchange rate appreciation. In such a case, one cannot say that changes in output and the current account are due to an autonomous change in the nominal exchange rate. General economic condition such as output, inflation, liquidity

\footnotetext{
${ }^{8}$ We also experimented with the quadratic trend. The results are similar.
} 
condition, current account balance, capital account balance, and monetary policy stance of domestic and foreign countries are the main factors affecting the nominal exchange rate. ${ }^{9}$ Therefore, we include these variables to control for endogenous movements of the exchange rate and to identify exogenous shocks to the exchange rate.

Equation (1) shows the reduced form model given by:

$$
\left(\begin{array}{c}
K A R_{t} \\
R Y_{t} \\
P_{t} \\
R M_{t} \\
C A R_{t} \\
E R_{t}
\end{array}\right)=\left(\begin{array}{l}
a_{1} \\
a_{2} \\
a_{3} \\
a_{4} \\
a_{5} \\
a_{6}
\end{array}\right)+A_{i j}(L)\left(\begin{array}{c}
K A R_{t-1} \\
R Y_{t-1} \\
C P I_{t-1} \\
R M_{t-1} \\
C A R_{t-1} \\
E R_{t-1}
\end{array}\right)+B_{i j}(L)\left(\begin{array}{c}
R Y F_{t} \\
R F_{t} \\
P F_{t}
\end{array}\right)+\left(\begin{array}{l}
\varepsilon_{1 t} \\
\varepsilon_{2 t} \\
\varepsilon_{3 t} \\
\varepsilon_{4 t} \\
\varepsilon_{5 t} \\
\varepsilon_{6 t}
\end{array}\right)
$$

where $A_{i j}(L)$ and $B_{i j}(L)$ are $6 \times 6$ and $6 \times 2$ matrices of polynomials in lag operator $L$, respectively.

The estimated reduced form model is converted to the structural form model by imposing zero restrictions on contemporaneous interactions among variables. The methodology is similar to the one popularized by Sims (1980). For the identifying restrictions, the exchange rate is contemporaneously affected by all endogenous variables but not the other way around. ${ }^{10}$ In other words, the effects of contemporaneous changes in the exchange rate due to other variables in the system are removed from innovations in the nominal exchange rate. This arrangement is designed to extract "pure" exchange rate shocks by eliminating the exchange rate changes that can be considered as endogenous reactions to other variables. Relatively exogenous changes in the exchange rate, such as those induced by "exogenous” policy changes, should remain as identified (structural) exchange rate shocks.

Such a treatment on the exchange rate in the structural VAR model is popular in past studies. Kim and Roubini (2000) and Kim (2003, 2005) assume that all variables in the model are allowed to affect the nominal exchange rate contemporaneously because it is a forward-looking

\footnotetext{
${ }^{9}$ Empirical evidence indicates that capital flows comprise one of the important determinants of exchange rate in a world of globalized capital movement (see Calvo, Leiderman, and Reinhart, 1996; Kamin and Rogers, 2000; Kim, 2000; Kim and Yang, 2011.

${ }^{10}$ Practically, we use a recursive VAR model as in Sims (1980), and the exchange rate is ordered at the bottom, that is, the exchange rate is contemporaneously affected by all endogenous variables. In such a model, the effects of exchange rate shocks on the other five variables are theoretically the same regardless of the ordering among the five variables (see Christiano, Eichenbaum, and Evans, 1999 for further discussion).
} 
variable that instantaneously reflects all types of information. Kim and Ying (2007) adopt a similar identifying assumption in examining the effects of devaluation in developing countries by analyzing shocks to the exchange rate. Even in an adjustable peg system, policy decisions on exchange rate changes (devaluation or revaluation) are likely to respond to economic condition endogenously. Therefore, it is important to identify exogenous changes in the exchange rate by controlling for its endogenous changes in order to analyze the effects of exchange rate changes on the economy.

In this work, we estimate the model for Japan and China using quarterly data. The estimation periods are 1977:1-2012:4 and 1990:1-2012:4 for Japan and China, respectively. ${ }^{11}$ Note that the estimation period of Japan includes the periods before and after the Plaza Agreement of September 1985. Details on data source are reported in the Appendix. ${ }^{12}$

\section{Empirical Results}

Figure 1 reports the impulse responses to exchange rate shocks over 16 quarters with 90\% probability bands. The responding variables are denoted at the top of each graph. The first two columns of the graphs show the results for China, while the last two are those for Japan. Note that the exchange rate is defined as US dollars per RMB or yen; thus, panels in Figure 1 show the responses to appreciation of the RMB or yen. Interestingly, the responses of output and the current account are quite different in the two countries.

In China, the exchange-rate shock appreciates the exchange rate by $3 \%$ on impact, which declines to the initial level in about 4 quarters; the responses up to three quarters are different from zero with 95\% probability. Neither the current account nor capital account responds significantly as indicated by wide probability bands. Real output decreases in the short-run, leading to the maximum decline of about $0.25 \%$ in three quarters, which is different from zero with 95\% probability. The price level tends to decrease. The real money decreases in the short run, but returns to the initial level in 6 quarters.

In Japan, exchange-rate shocks appreciate the exchange rate by over $4 \%$ on impact but returns to the initial level in about 9 quarters. The current account worsens significantly with

\footnotetext{
${ }^{11}$ The estimation period for Japan was determined by the availability of capital account data.

${ }^{12}$ Our statistical inference is not problematic in the presence of unit roots and cointegrating relations since we follow the Bayesian inference. See Sims (1988) and Sims and Uhlig (1991) for general discussion on Bayesian inference in the presence of unit roots and cointegrating relations.
} 
more than $95 \%$ probability. The maximum decline of the current account (about $0.25 \%$ of trend GDP) is found in about 8 quarters. The current account returns to the initial level in the long run. The price level decreases gradually over time and decreases by about $0.23 \%$ after 8 quarters. The capital account increases by about $0.075 \%$ in the short run, which is different from zero with a 95\% probability. The responses of real GDP and real money balance are not different from those of zero with $95 \%$ probability.

To investigate the responses of the current account and output in greater detail, we extend the model by including various components of trade-related variables one by one. ${ }^{13}$ We consider exports in the local currency (XP, as a ratio to the trend GDP), imports in local currency (MP, as a ratio to the trend GDP), export price in local currency (PXP), import price in local currency (PMP), export price in US dollars (DPXP), and import price in U.S. dollars (DPMP). In addition, we assume that the exchange rate is allowed to affect each additional variable contemporaneously, but not the other way around. ${ }^{14}$

Figure 2 shows the results. In China, export and import prices in terms of U.S. dollars do not change much, while their prices in RMB decline sharply with an appreciation of the domestic currency. The results are consistent with the dollar pricing story discussed in Section 2. Under dollar pricing, the response of exports in RMB is mainly due to the value effect as the dollar price of exports remains unchanged. The response of imports in RMB is a combination of the price and volume effects because import demand increases as the RMB prices of imports decline. However, the responses in exports (XP) and imports (MP) appear to be similar. This implies that the price elasticity of import demand is small and, thus, the volume effect is negligible. There can be many reasons for this low price elasticity of imports, but the vertical trade integration story is consistent with the finding considering that the quantity of imports is closely related to the quantity of exports instead of import prices under vertical trade integration.

In Japan, the results are quite different. The dollar prices of exports and imports increase while the yen prices of exports and imports decline. This reflects intermediate or partial pass-

\footnotetext{
${ }^{13}$ Throughout the paper, we extended the baseline model by adding various variables one by one. In most cases, the responses of the existing variables in the extended models are similar to those in the baseline models.

${ }^{14}$ Given that we control most important variables that affect the exchange rate, it may be justified not to allow the additional variable to affect the exchange rate contemporaneously. In fact, restricting the contemporaneous responses may not be justifiable for some cases. For example, when the exchange rate changes, either dollar- or local currency prices of exports and imports are likely to change immediately.
} 
through. ${ }^{15}$ Exports in terms of the Japanese yen decrease, which can be due to both the volume effect (as the U.S. dollar price of exports increases) and the value effect (as the yen price of exports declines). Imports in yen also decrease in the short run, but it increases over time. The result seems to suggest that, as the yen price of imports declines, the value effect dominates in the short run; meanwhile, as the price declines, the volume effect takes over in the longer run. In the short run, current account does not change much because the value effect decreases both exports and imports. Subsequently, however, current account worsens as the volume effect decreases exports and increases imports.

Figure 3 reports the effects on bilateral trade relationship with the U.S. Here, the responses of six variables are reported: TB_US (trade balance with the U.S. in domestic currency), DTB_US (trade balance with the U.S. in US dollars), XP_US (exports to the U.S. in domestic currency), DXP_US (exports to the U.S. in US dollars), MP_US (imports from the U.S. in domestic currency), and DMP_US (imports from the U.S. in US dollars). All variables are constructed as ratios to the trend GDP. The results are similar to those of the overall current account/trade balance. In China, the trade balance against the U.S. does not decrease. This is because both exports and import move together in the same direction. Exports and imports do not change much in terms of U.S. dollars, but significantly decrease in terms of the RMB. In Japan, the trade balance against the U.S. worsens. Both exports and imports increase in dollar terms in the short run. However, in yen terms, both decline in the short run.

Figure 4 shows the responses of various components of GDP to exchange rate shocks. RC, RG, IVR, and SVR stand for real consumption, real government consumption, fixed investment, and national saving. ${ }^{16}$ IVR and SVR are measured as ratio to trend GDP. In China, private consumption decreases in the short run, which contributes to the decline in real GDP after exchange rate appreciation (Figure 1). ${ }^{17}$ This may be related to the decrease in real money balance following currency appreciation (Figure 1) and the decline in government consumption

\footnotetext{
${ }^{15}$ Unlike the case of China, all responses of prices appear to be temporary. This is not surprising because the exchange rate appreciation is also temporary in Japan.

${ }^{16}$ For real variables (RC and RG), we assume that the exchange rate is contemporaneously exogenous to these variables. This is consistent with the baseline model in which the exchange rate is contemporaneously exogenous to a real variable (output). In addition, real macro aggregate variables are often viewed as moving sluggishly (for example, see Kim, 1999, Kim and Roubini, 2000, and Sims and Zha, 2005).

${ }^{17}$ Although not reported in Figure 4, investment in real term also decreases in China, which also contributes to the decline in real GDP after exchange rate appreciation.
} 
(Figure 4). ${ }^{18}$ The responses of national saving and investment are not too much different, which is consistent with the small effect on current account.

In Japan, private consumption tends to increase. Government consumption also increases sharply. Real GDP does not change much in response to yen appreciation despite a significant worsening of the current account (Figure 1). This suggests that the reduction in the current account is offset by an increase in private and government consumption. Capital inflows after appreciation (in Figure 1) and fiscal expansion (that may have been taken to avoid the recessionary effect of exchange rate appreciation), may have contributed to generate a positive effect on consumption. National saving decreases persistently while investment moves little. This is also consistent with the current account worsening in Japan.

\section{Extended Results}

\subsection{Alternative Identification Scheme}

The baseline model assumes that all variables are allowed to affect the exchange rate contemporaneously but not the other way around. In this section, an alternative identification scheme is considered to examine the robustness of the results. The alternative model assumes the opposite ordering on the contemporaneous interactions among variables, such that the exchange rate is allowed to affect all endogenous variables contemporaneously but not the other way around. The results, reported in the first and the third columns of panels in Figure 5, are qualitatively similar to those of the baseline model in most cases. With an appreciation of the domestic currency, the current account declines significantly in Japan but is little affected in China. The effect on output in Japan is still insignificant, but the recessionary effect is observed in China.

\subsection{Extended Model}

First, we add the domestic interest rate $(\mathrm{R})$ to the model. The second and the fourth columns in Figure 5 report the results. Given that changes in the interest rate can affect the exchange rate contemporaneously, the interest rate is allowed to affect the exchange rate, but not the other way

\footnotetext{
${ }^{18}$ The impulse responses of real money balance (reported in Figures 1) suggest that the currency appreciation may be induced or accompanied by monetary contraction. In addition, contractionary fiscal policy (or a fall in government consumption) is also found (reported in Figure 4).
} 
around. The results on output and current account are qualitatively similar to those from the baseline model. In addition, we can see that the currency appreciation is associated with a significant reduction in the interest rate in Japan but not in China. The interest rate reduction in Japan may be related to liquidity expansion following capital inflows (Figure 1) or monetary expansion to avoid the recessionary effects from currency appreciation. On the other hand, less significant responses of interest rate in China might be due to capital controls. Alternatively, it may be related to the interest rate not being used as the monetary instrument in China.

Second, the effective exchange rate is used instead of the bilateral exchange rate against the U.S. dollar. The panels in the first and the third columns in Figure 6 report the results. The results are qualitatively similar to those in the baseline model. In China, the current account does not respond significantly, while output decline is significant as in the baseline model. In Japan, the current account improves but output does not respond significantly.

Third, the real exchange rate against the U.S. is used instead of the nominal exchange rate against the U.S. CPI is used to construct the real exchange rate. The panels in the second and the fourth columns in Figure 6 report the results. The main results remain unaffected.

\section{Conclusion}

China has been under tremendous pressure to let its currency appreciate and move to a floating exchange rate regime. Many argue that the RMB is undervalued, thereby causing huge imbalances in the current account balances with the U.S. Thus far, China has been resisting

pressure to change its own exchange rate policy on the grounds that RMB appreciation can handicap its crucial export sector and create a host of economic problems, including a deceleration in economic growth which would worsen the unemployment problem in the rural sector. Its resistance has also been partly based on the Japanese experience of undergoing a decades-long recession following huge appreciation.

Existing studies show a wide array of estimates of RMB undervaluation or even overvaluation. Recommendations for the desirable exchange rate in China appear to be equally confusing as well. In this backdrop, we present empirical evidence by employing structural VAR model that shows some important differences between the experiences of Japan and China. Currency appreciation in Japan reduces current account surpluses, which is consistent with the 
popular notion, although it does not induce economic downturn contrary to what many people argue. On the other hand, RMB appreciation is not likely to have any significant effects on the current account balance but have a negative effect on real GDP in China. These results suggest that pressuring China to undertake RMB appreciation for the purpose of current account adjustment may be ill guided. On the other hand, they give a moderate support to the claim that currency appreciation will give recessionary pressure in the Chinese economy. Our results also suggest that attributing Japan's long recession to the yen appreciation is not necessarily warranted. There is little or no evidence showing that the appreciation of the yen leads to output contraction in Japan.

Further empirical analysis suggests that “dollar pricing," possibly combined with vertical trade integration, provides a clue to insignificant responses of Chinese current account to exchange rate shocks. Given that both exports and imports are set in terms of the U.S. dollar, the value effects from an RMB appreciation decrease both exports and imports in terms of RMB, offsetting each other. In addition, China's imports do not seem to strongly respond to the increase in the RMB import price, which is consistent with the vertical trade integration story. On the other hand, Japan seems to be the case of partial pass-through of exchange rate changes in which expenditure switching effect is more relevant than in China.

The empirical results also suggest that the decline of output in response to currency appreciation in China is due to a reduction in consumption and investment, which seems to be related to the decline in real money balance and government consumption. On the other hand, Japan's output response to the exchange rate changes is weak and insignificant. This is because a significant decline the current account is offset by an increase in private and government consumption, which may be induced by capital inflows following the yen appreciation and endogenous fiscal policy.

Would currency appreciation cure the problem of global imbalances as argued by many economists and the U.S. government? Our empirical results indicate that China's current account surpluses are unlikely to decline significantly with RMB appreciation. If the sole basis of recommending currency appreciation for China is to reduce the current account surplus, we might be disappointed with the outcome. On the other hand, the currency appreciation is likely to decrease inflationary pressure in Chinese economy although it may have some negative effect on consumption and investment. 


\section{Appendix: Data Sources}

\section{A1. China}

Data on GDP and its components (and their deflators), short-term interest rate, CPI are obtained from the Oxford Economics Macro Database. The difference between exports and imports of goods and services is used as the current account. Deflators for exports and imports are used as prices of exports and imports in RMB term. The prices of exports and imports in U.S. dollar terms are obtained by dividing them by the RMB-U.S. dollar exchange rate. The capital account balance is approximated as changes in reserves minus the current account. Data on reserves, nominal exchange rate against the U.S. dollars (period average) and nominal effective exchange rate are obtained from International Financial Statistics (IMF). Data on bilateral trade balance, exports, and imports are obtained from Direction of Trade Statistics (IMF). Seasonally unadjusted data is seasonally adjusted using the X 11 method, except for the nominal exchange rate and the interest rate.

For Section 5.5., industrial production, nominal and real GDP, as well as exports and imports are obtained from International Financial Statistics. CPI is obtained from OECD Economic Outlook. Sources for other data series are the same as the ones for the whole sample period estimations. Seasonally unadjusted data is seasonally adjusted using the X 11 method, except for the nominal exchange rate and the interest rate.

\section{A2. Japan}

Data on GDP and its components (and their deflators) are obtained from the OECD Quarterly National Account. The difference between exports and imports are used as the current account. Deflators for exports and imports are used as prices of exports and imports in Japanese Yen term. The prices of exports and imports in U.S. dollar terms are obtained by dividing them by the Japanese Yen-U.S. dollar exchange rate. All other data series are obtained from International Financial Statistics. The sum of financial and capital accounts is used as the capital account. The call money rate is used as the short-term interest rate. Data on bilateral trade balance, exports, and imports are obtained from Direction of Trade 
Statistics. Seasonally unadjusted data is seasonally adjusted using the X 11 method, except for the nominal exchange rate and the interest rate.

A3. The U.S.

All data series are obtained from International Financial Statistics. 3-month Treasury bill rate is used as the short-term interest rate. 


\section{References}

Ahmed, S. “Are Chinese Exports Sensitive to Changes in the Exchange Rate?” International Finance Discussion Paper 978, Board of Governors of the Federal Reserve System, 2009.

Betts, C. and M.B. Devereux. "Exchange Rate Dynamics in a Model of Pricing-to-Market.” Journal of International Economics, (2000): 50, 215-244.

Bosworth, B. "Valuing the RMB," presented at the Tokyo Club Research Meeting, February, 2004.

Buffie, E.F. "Imported Inputs, Real Wage Rigidity and Devaluation in the Small Open Economy." European Economic Review, (1989): 33 (7), 1345-1361.

Calvo, G.A., Leiderman, L. and Reinhart, C.M. "Inflows of Capital to Developing Countries in the 1990s.” The Journal of Economic Perspectives, (1996): 10, 2, 123-139.

Cespeds, L.F., Chang, R. and Velasco, A. "Balance Sheets and Exchange Rate Policy.” American Economic Review, (2004): 94 (4), 1183-1193.

Cheung, Y., Chinn, M. and Fuji, E. "Measuring Misalignment: Latest Estimates for the Chinese Yuan.” 2010.

Cheung, Y., Chinn, M. and Fuji, E. "Pitfalls in Measuring Exchange Rate Misalignment: The Yuan and Other Currencies.” Open Economies Review, (2009): 20 (2), 183-206.

Cheung, Y., Chinn, M. and Fuji, E. “The Overvaluation of Renminbi Undervaluation.” Journal of International Money and Finance, (2007): 26 (5), 762-785.

Chinn, M. D. and Wei, S.J. “A Faith-based Initiative: Does a Flexible Exchange Rate Regime Really Facilitate Current Account Adjustment.” NBER Working Paper No. 14420, 2008.

Christiano, L., Eichenbaum, M., and Evans, C. "Monetary Policy Shocks: What Have We Learned and to What End?” In Handbook of Macroeconomics. Vol. 1A, pp 65-148. Edited by Taylor, J.B. and Woodford, M. North-Holland, Amsterdam, 1999.

Cline, William, and John Williamson, 2008, "Estimates of the Equilibrium Exchange Rate of the Renminbi?” Edited by Goldstein, M. and Lardy, N. in Debating China's Exchange Rate Policy. Peterson Institute for International Economics: Washington DC, 131-154.

Cook, D. and Devereux, M.B. "External Currency Pricing and the East Asian Crisis," Journal of International Economics, (2006): 69 (1), 37-63.

Cooper, R. "Currency Depreciation in Developing Countries.” Princeton Essays in International Finance 86, Princeton University: 1971.

Coudert, V. and Couharde, C. "Real Equilibrium Exchange Rate in China.” CEPII Working Paper 2005-01, Paris. January, 2005.

Diaz-Alejandro, C.F. "A Note on the Impact of Devaluation and the Redistributive Effects." Journal of Political Economy, (1963): 71 (6), 577-580.

Dunaway, S.V., Leigh, L. and Li, X. "How Robust are Estimates of Equilibrium Real Exchange Rates: The Case of China,” Pacific Economic Review, (2009): 14(3), 361-375.

Findlay, R., Rodriguez, C.A. "Intermediated Imports and Macroeconomic Policy under Flexible Exchange Rates.” Canadian Journal of Economics, (1977): 10 (2), 208-217.

Frankel, J. "On the Yuan: The Choice between Adjustment Under a Fixed Exchange Rate and Adjustment under a Flexible Rate." In Understanding the Chinese Economy. Edited by Gerhard Illing, 246-275. Oxford University Press, 2006.

Frankel, J. "New Estimation of China’s Exchange Rate Regime.” Pacific Economic Review, (2009): 14 (3), 346-60.

Frenkel, J.A., Johnson, H.C. "The Monetary Approach to the Balance of Payments: Essential Concepts and Historical Origins.” In The Monetary Approach to the Balance of Payments. 
pp. 21-45. Edited by Frankel, J.A. Johnson, H.C. University of Toronto Press, Allen \& Unwin, 1976.

Funke, M. and Rahn, J. “Just How Undervalued is the Chinese Renminbi?” World Economy, (2005): 28(4), 465-89.

GAO (United States Government Accountability Office). “International Trade: Treasury Assessment Have Not Found Currency Manipulation, But Concerns about Exchange Rates Continue.” (2005): GAO-05-351.

Garcia-Herrero, A. and Koivu, T. "Can the Chinese Trade Surplus Be Reduced through Exchange Rate Policy?” BOFIT Discussion Papers No. 2007-6 (Helsinki: Bank of Finland, March), 2007.

Garten, P. and Chang, J. "The Chinese Currency: How Undervalued and How Much Does it Matter?” Economic Roundup, (2005): 83-109.

Goldstein, M. “Renminbi Controversies.” Cato Journal, (2006): 26 (2), 251-266.

Goldstein, M. and Lardy, N.R. "The Future of China's Exchange Rate Policy." Peterson Institute for International Economics: Washington, DC, 2009.

Gylfason, T. and Risager, O. “Does Devaluation Improve the Current Account?” European Economic Review, (1984): 25(1), 37-64.

Kamin, S.B. and Rogers, J.H. "Output and the Real Exchange Rate in Developing Countries: An Application to Mexico,” Journal of Development Economics, (2000); 61, 85-109.

Kim, Soyoung, "Monetary Policy, Foreign Exchange Intervention, and Exchange Rate in a Unifying Framework.” Journal of International Economics, (2003): 60, 355-386.

Kim, S. "Monetary Policy, Foreign Exchange Policy, and Delayed Overshooting," Journal of Money, Credit, and Banking, (2005): 37, 775-782.

Kim, S., Lee, J.W. and Park, C.Y. "Ties Binding Asia, Europe, and the United States.” China \& World Economy, (2011): 19(1), 24-46.

Kim, S., and Roubini, N. "Exchange Rate Anomalies in the Industrial Countries: A Solution with a Structural VAR Approach,” Journal of Monetary Economics, (2000): 45, 3, 561-586.

Kim, S., and Yang, D.Y. "The Impact of Capital Inflows on Asset Prices in Emerging Asian Economies: Is Too Much Money Chasing Too Little Good?” Open Economies Review, (2011): 22(1), 293-315.

Kim, Y. "Causes of Capital Flows in Developing Countries." Journal of International Money and Finance, (2000): 19(2), 235-253.

Kim, Y. and Ying, Y.H. "An Empirical Assessment of Currency Devaluation in East Asian Countries.” Journal of International Money and Finance, (2007): 26, 265-283.

Koopman, R., Wang, Z. and Wei, S.J. "How Much of Chinese Exports is Real Made in China? Assessing Domestic Value-Added When Processing Trade is Pervasive.” NBER Working Paper \# 14109, 2008.

Krugman, P., Talyor, L. “Contractionary Effects of Devaluation.” Journal of International Economics, (1978): 8 (3), 445-456.

Kwack, S.Y., Ahn, C.Y., Lee, Y.S. and Yang, D.Y. "Consistent Estimates of World Trade Elasticities and an Application to the Effects of Chinese Yuan (RMB) Appreciation," Journal of Asian Economics, (2007): 18: 314-330.

Liao, W., Kang, S. and Zhang, Z. "Vertical Trade and China’s Export Dynamics.” Working Paper, Hong Kong Institute for Monetary Research, 2010.

Marquez, J. and Schindler, J.W. "Exchange-Rate Effects on China’s Tade.” Review of International Economics, (2007): 15(5), 837-853. 
Marston, R.C. "Wages, Relative Prices and the Choice Between Fixed and Flexible Exchange Rates,” Canadian Journal of Economics, (1982): 15 (1), 87-103.

McKinnon, R. "Why China Should Keep Its Dollar Peg," International Finance, (2007): 10(1), 4370.

Mundell, R. “Adjustment in China's Exchange Rate Regime.” Remarks at Inaugural Seminar on Foreign Exchange System.” Dalian, China, May 26-27, 2004.

Obstfeld, M. and K. Rogoff, "Exchange Rate Dynamics Redux,” Journal of Political Economy, (1995): 103, 624-660.

Roubini, N. "Why China Should Abandon Its Dollar Peg," International Finance 10(1), 71-89.

Sachs, J. "Wages, Flexible Exchange Rates, and Macroeconomic Policy." Quarterly Journal of Economics, (1980): 94 (4), 31-47.

Shi, J. “Are Currency Appreciations Contractionary in China?” NBER Working Paper, (2006): 12551.

Sims, C.A. "Macroeconomics and Reality," Econometrica, (1980): 48:1-48.

Sims, C.A. "Bayesian Skepticism on Unit Root Econometrics," Journal of Economic Dynamics and Control, (1988): 12, 463--74.

Sims, C.A., Uhlig, H. “Understanding Unit Rooters: A Helicopter Tour,” Econometrica, (1991): 59, 1591--99.

Subramanian, A. "New PPP-Based Estimates of Renminbi Undervaluation and Policy Implications." Policy Brief 10-8. Peterson Institute for International Economics: Washington DC, April, 2010.

Tatom, J.A. "The US-China Currency Dispute: Is a Rise in the Yuan Necessary, Inevitable or Desirable?” Global Economy Journal, (2007): 7 (3), Article 2.

Thorbecke, W. and Smith, G. "How Would an Appreciation of the RMB and Other East Asian Currencies Affect China’s Exports?” Review of International Economics, (2010): 18(1), 95108.

Xu, Y., “China’s Exchange Rate Policy,” China Economic Review, (2000): 11: 262-277. 
Table 1: A Summary of Estimates for the RMB Under- or Over-valuation

\begin{tabular}{|c|c|c|c|c|}
\hline Authors & Method (data) & Year & $\begin{array}{l}\text { Undervaluation } \\
\text { (overvaluation if (-)) }\end{array}$ & Comment \\
\hline Economist & Absolute PPP & 2010 & 47 & Big Mac standard \\
\hline Frankel (2005) & PPP with B-S effects & 2000 & 36 & \\
\hline \multirow{2}{*}{$\begin{array}{l}\text { Coudert and } \\
\text { Couharde (2005) }\end{array}$} & PPP with B-S effects & 2003 & $43-50$ & \\
\hline & FEER & 2003 & 23 & \\
\hline $\begin{array}{l}\text { Garton and Chang } \\
\text { (2005) }\end{array}$ & PPP with B-S effects & 2005 & 25 & \\
\hline $\begin{array}{l}\text { Subramanian } \\
(2010)\end{array}$ & PPP with B-S effects & 2005 & $14.5-47.5$ & \\
\hline $\begin{array}{l}\text { Cheung, Chinn, } \\
\text { and Fujii (2009) }\end{array}$ & $\begin{array}{l}\text { Productivity approach } \\
(1988-2004)\end{array}$ & 2004 & $1.4-6.1$ & \\
\hline $\begin{array}{l}\text { Cline and } \\
\text { Williamson (2010) }\end{array}$ & FEER & $\begin{array}{l}\text { March } \\
2009\end{array}$ & 32.8 & $\begin{array}{l}\text { Macroeconomic Balance } \\
\text { Approach }\end{array}$ \\
\hline $\begin{array}{l}\text { Goldstein and } \\
\text { Lardy (2009) }\end{array}$ & FEER & $\begin{array}{l}\text { End } \\
2008\end{array}$ & $20-25$ (level) & CA balance for China \\
\hline \multirow[t]{4}{*}{$\begin{array}{l}\text { Cheung, Chinn, } \\
\text { and Fujii (2010) }\end{array}$} & $\begin{array}{l}\text { Relative PPP } \\
(1980-2009)\end{array}$ & 2009 & $\begin{array}{l}7.5 \\
36\end{array}$ & $\begin{array}{l}\text { Without trend } \\
\text { With trend }\end{array}$ \\
\hline & $\begin{array}{l}\text { Relative PPP } \\
(1990-2009)\end{array}$ & 2009 & $\begin{array}{l}13.5 \\
1.6\end{array}$ & $\begin{array}{l}\text { Without trend } \\
\text { With trend }\end{array}$ \\
\hline & $\begin{array}{l}\text { Absolute PPP } \\
(1980-2009)\end{array}$ & 2008 & 50 & \\
\hline & $\begin{array}{l}\text { Absolute PPP/Penn } \\
\text { effect } \\
(1980-2009)\end{array}$ & 2008 & (-) 5 & \\
\hline $\begin{array}{l}\text { Funke and Rahn } \\
(2005)\end{array}$ & Relative PPP & $\begin{array}{l}\text { April } \\
2003\end{array}$ & 56 & Big Mac standard \\
\hline $\begin{array}{l}\text { Cheung, Chinn, } \\
\text { and Fujii (2007) }\end{array}$ & $\begin{array}{l}\text { Absolute PPP } \\
(1975-2004)\end{array}$ & 2004 & 53 & \\
\hline
\end{tabular}


Table 2. Implications of RMB Appreciation

\begin{tabular}{|l|l|l|l|l|l|l|l|l|}
\hline & $\begin{array}{l}\text { P(ex) } \\
\text { RMB }\end{array}$ & $\begin{array}{l}\text { P(ex) } \\
\$\end{array}$ & $\begin{array}{l}\text { P(im) } \\
\text { RMB }\end{array}$ & $\begin{array}{l}\text { P(im) } \\
\$\end{array}$ & $\begin{array}{l}\text { Value } \\
\text { export }\end{array}$ & $\begin{array}{l}\text { Volume } \\
\text { export }\end{array}$ & $\begin{array}{l}\text { Value } \\
\text { import }\end{array}$ & $\begin{array}{l}\text { Volume } \\
\text { Import }\end{array}$ \\
\hline PCP & - & $\uparrow \uparrow$ & $\downarrow \downarrow$ & - & - & $\downarrow \downarrow$ & $\downarrow \downarrow$ & $\uparrow \uparrow$ \\
\hline LCP & $\downarrow \downarrow$ & -- & -- & $\uparrow \uparrow$ & $\downarrow \downarrow$ & -- & -- & -- \\
\hline Intermediate & $\downarrow$ & $\uparrow$ & $\downarrow$ & $\uparrow$ & $\downarrow$ & $\downarrow$ & $\downarrow$ & $\uparrow$ \\
\hline ECP & $\downarrow \downarrow$ & -- & $\downarrow \downarrow$ & -- & $\downarrow \downarrow$ & -- & $\downarrow \downarrow$ & $\uparrow \uparrow$ \\
\hline
\end{tabular}

PCP: Producer Currency Pricing

LCP: Local Currency Pricing

Intermediate: Intermediate case between PCP and LCP

ECP: External Currency Pricing (\$ Pricing) 


\section{Figure 1. Impulse Responses to Exchange Rate Shocks: Baseline model}

\section{CHINA}
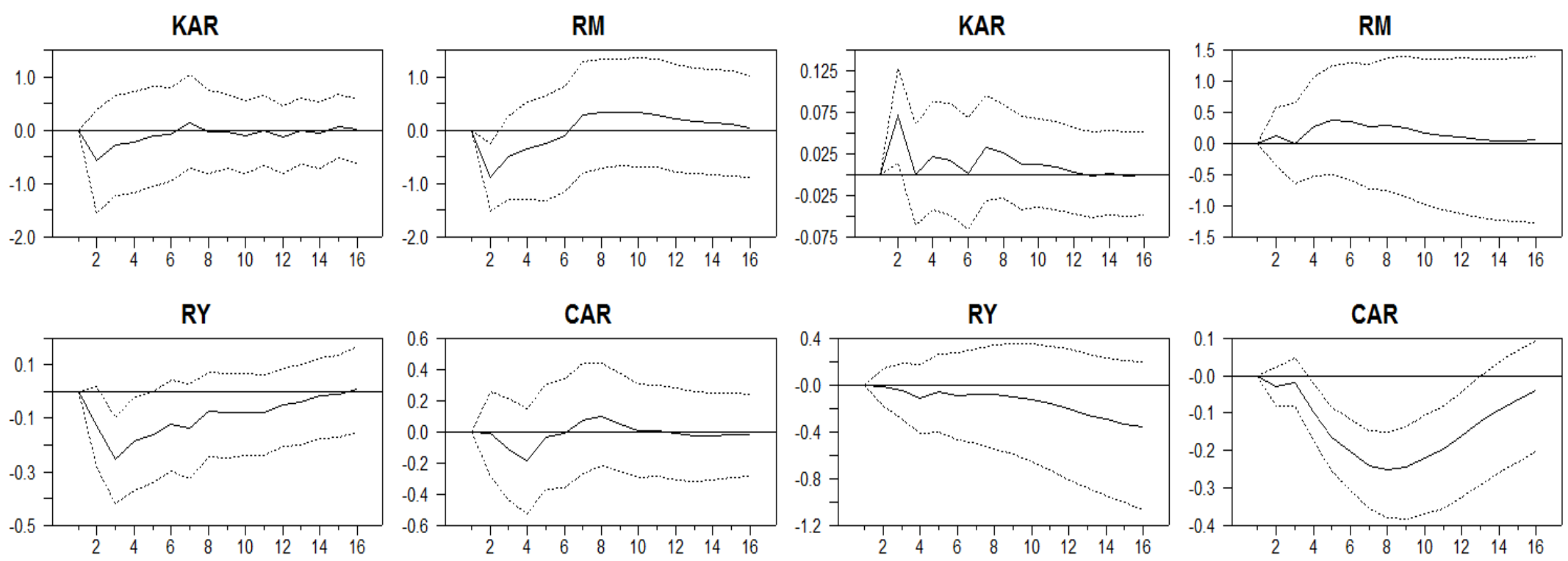

ER

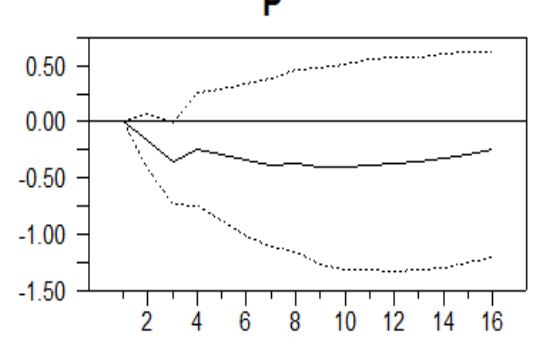

\section{JAPAN}

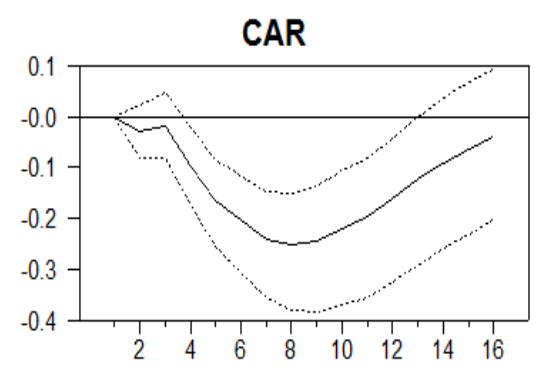

ER
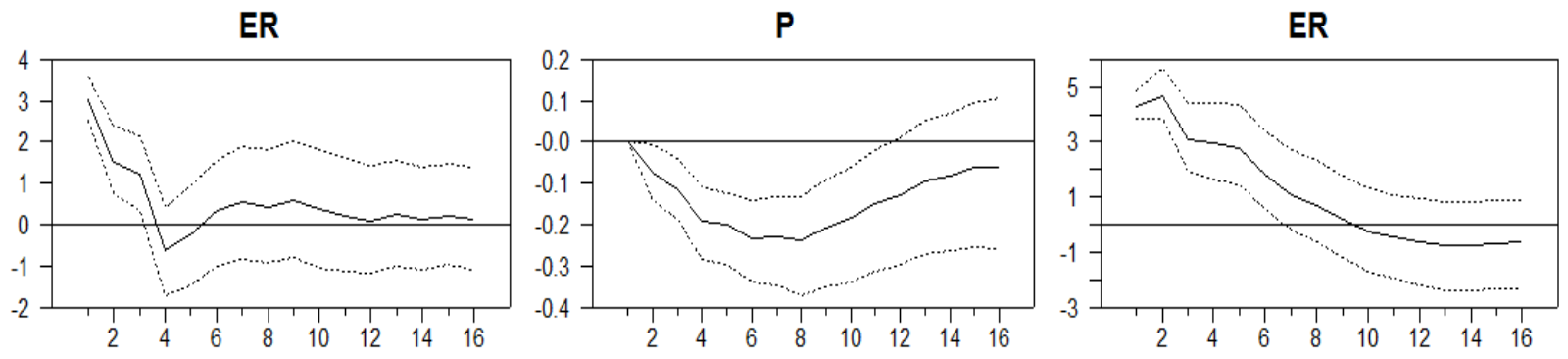
Figure 2. Impulse Responses to Exchange Rate Shocks: Exports and Imports

\section{CHINA}

$\mathrm{XP}$
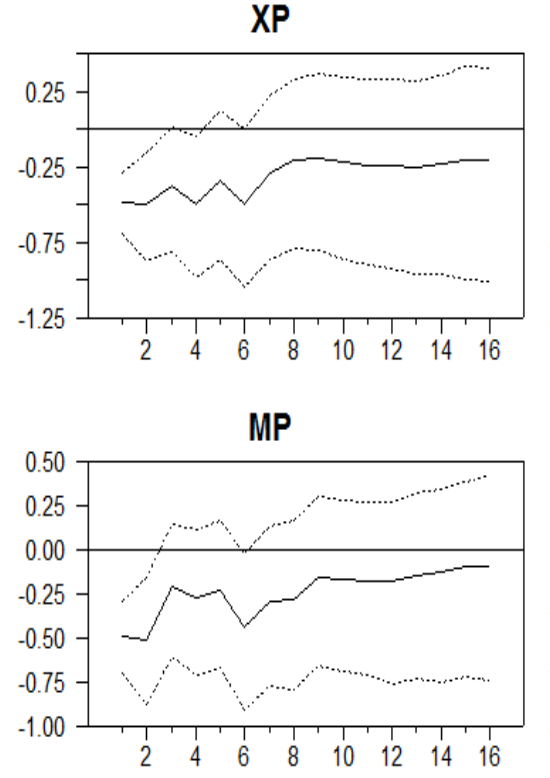

PXP

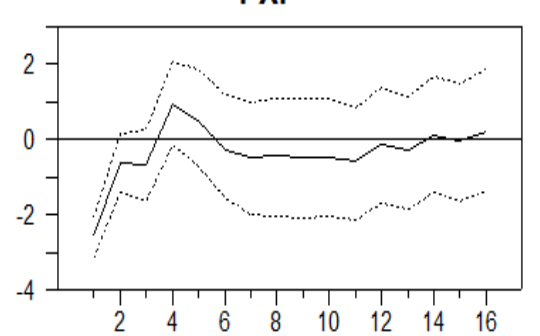

PMP

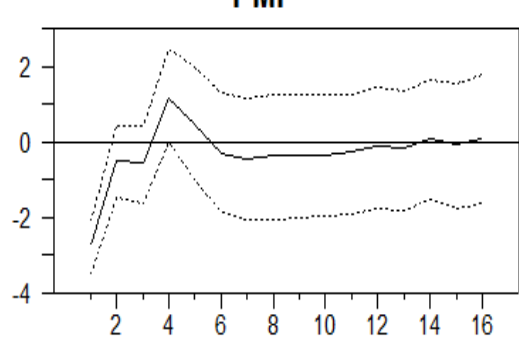

DPXP

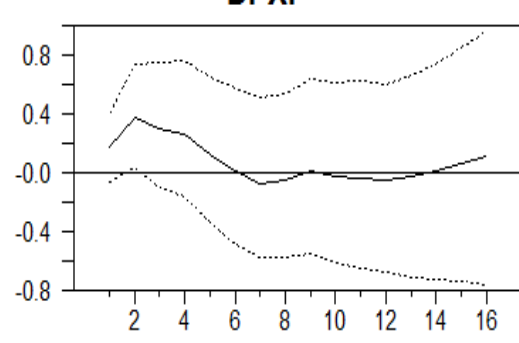

DPMP

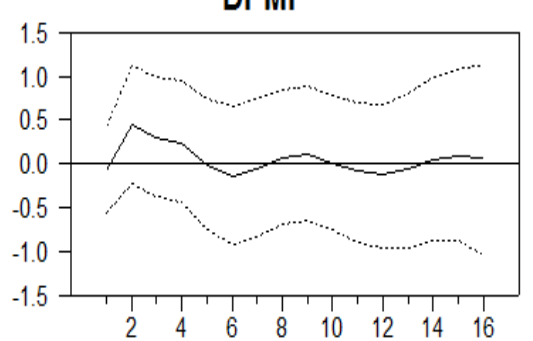

JAPAN
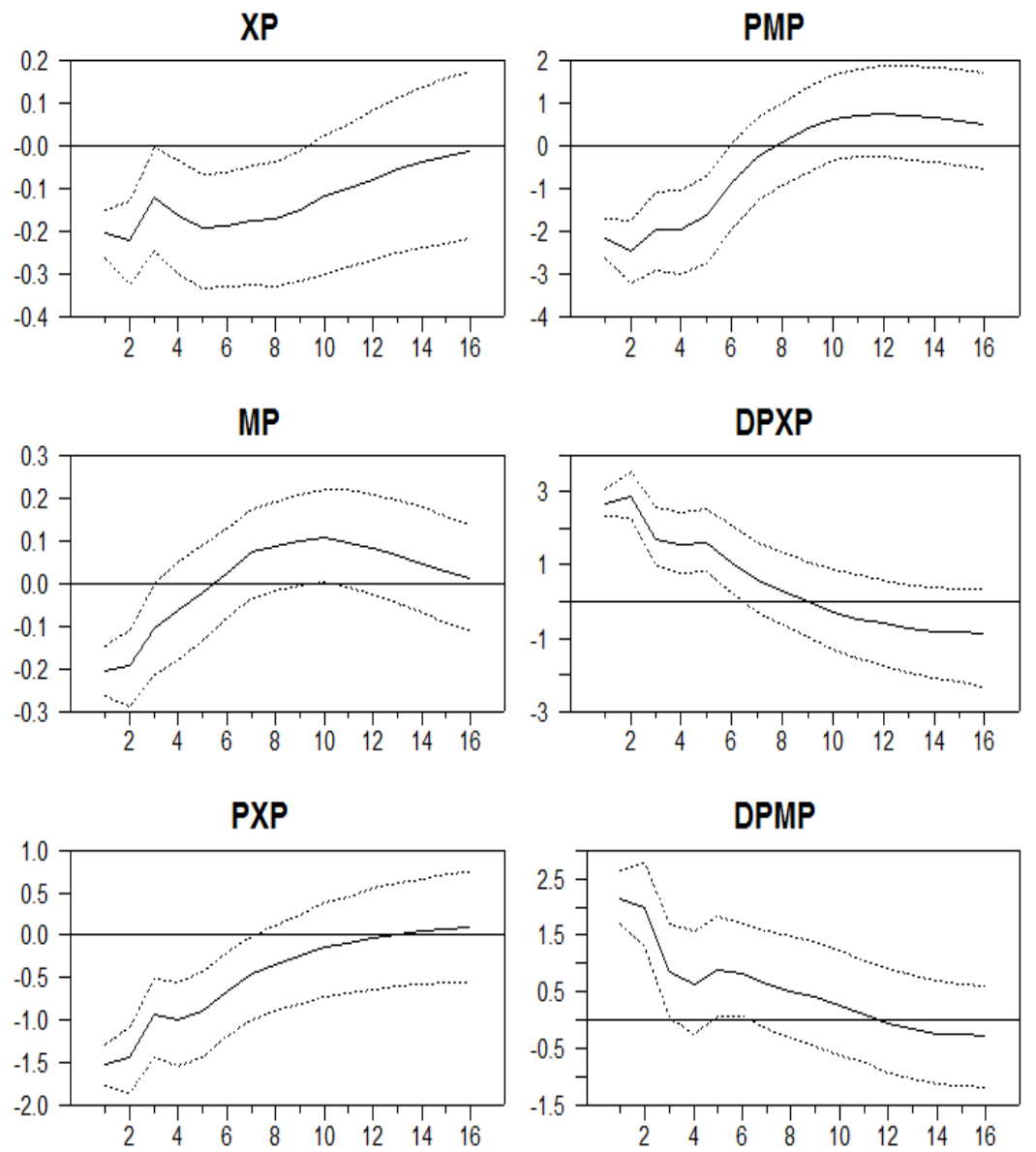
Figure 3. Impulse Responses to Exchange Rate Shocks: Trade Balance, Exports, and Imports against the U.S.

\section{CHINA}
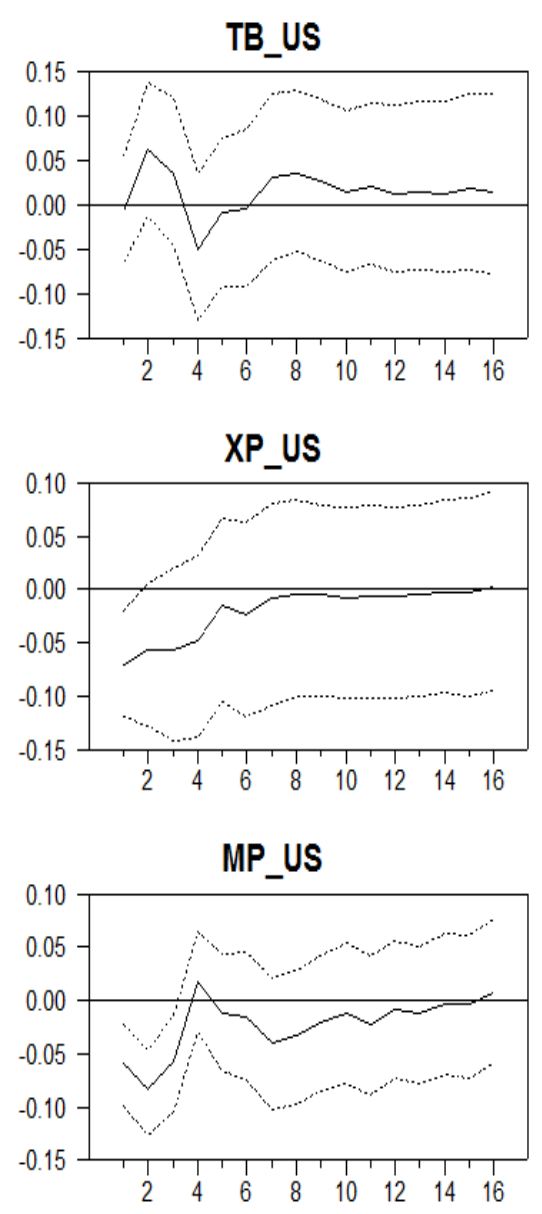
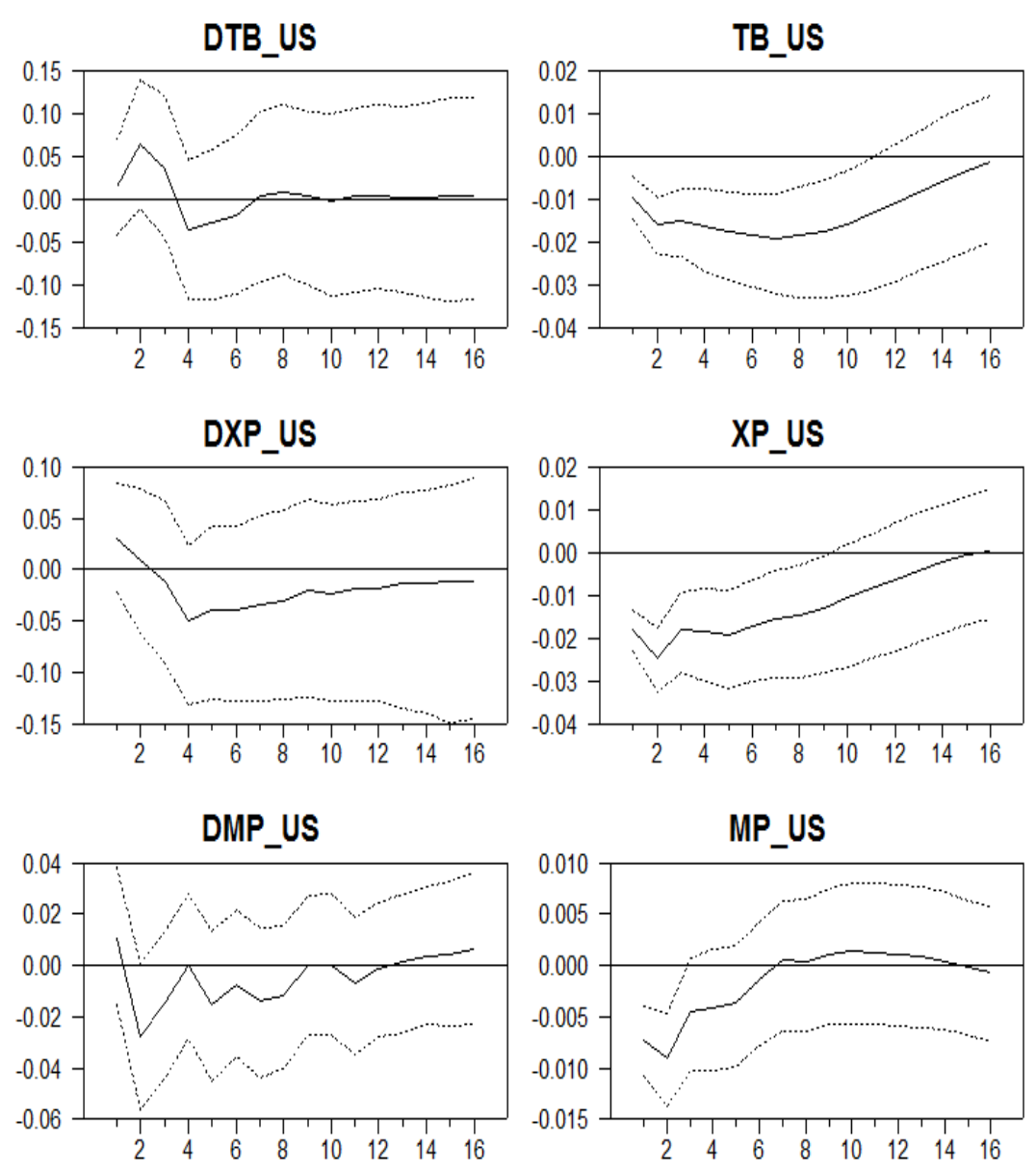

JAPAN

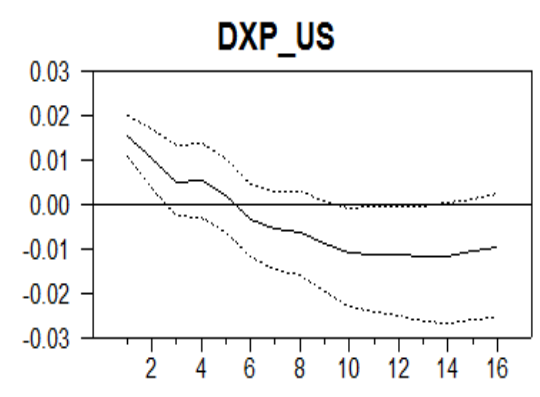


Figure 4. Impulse Responses to Exchange Rate Shocks: GDP Components

\section{CHINA}
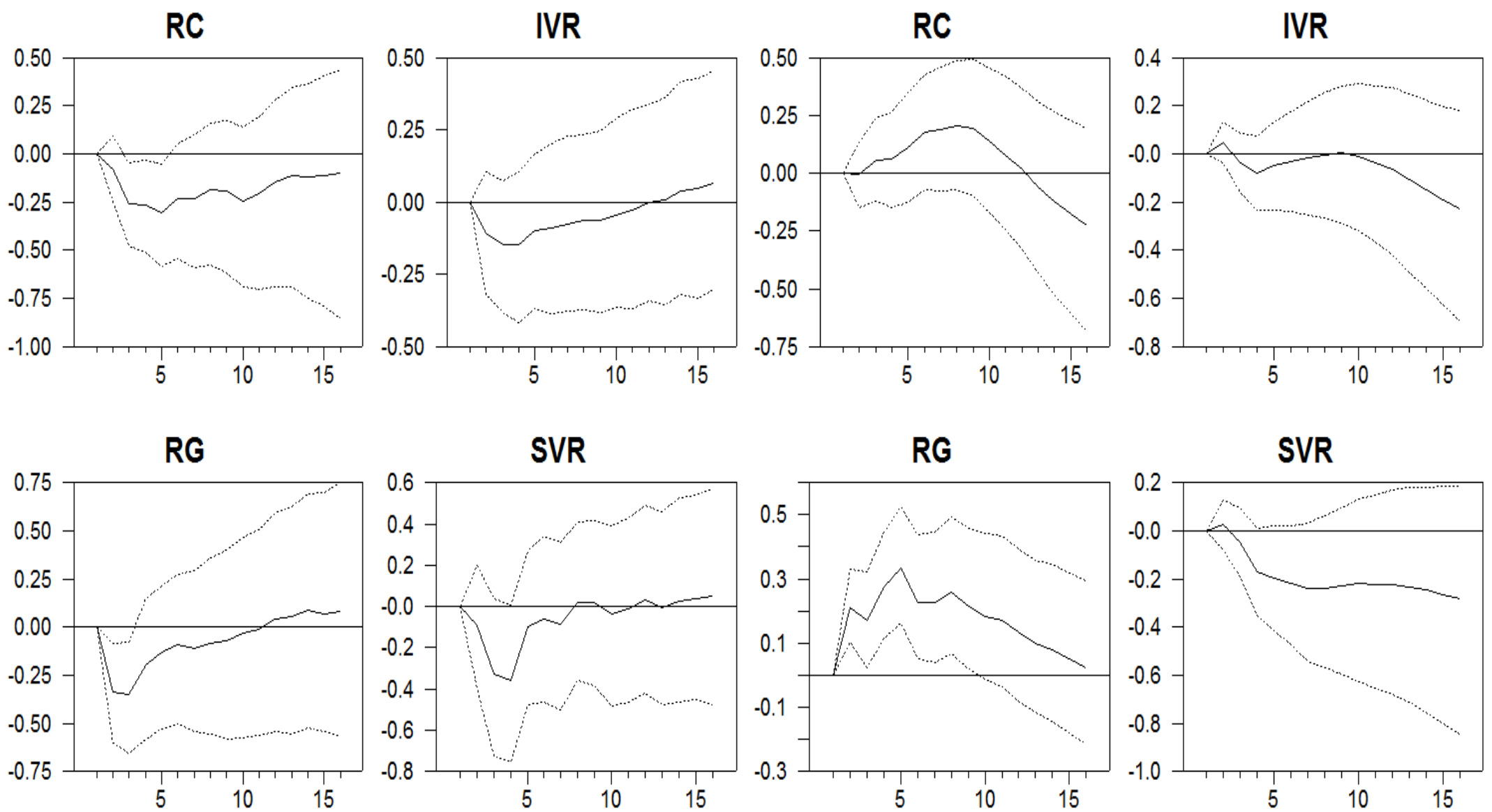
Figure 5. Impulse Responses: Alternative Identification Scheme and Adding Interest Rate

CHINA

Alternative Identification

ER

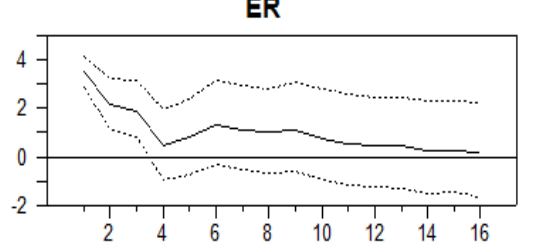

RY

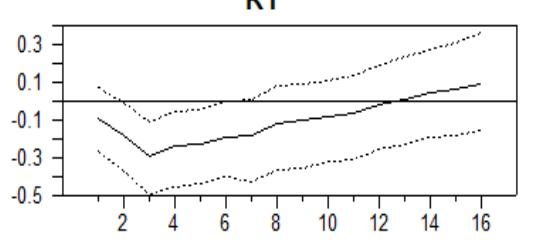

CAR
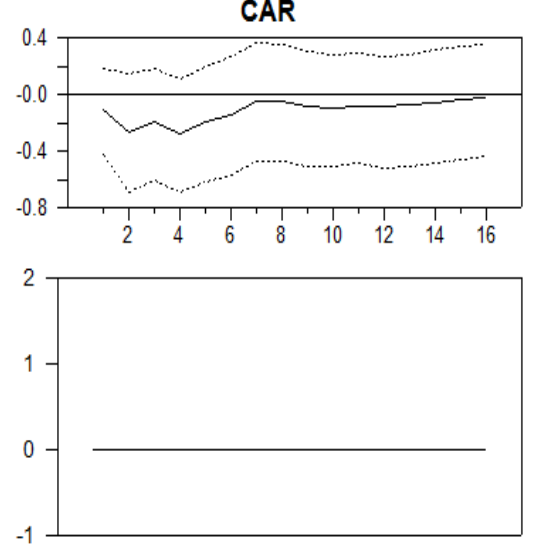

Interest Rate

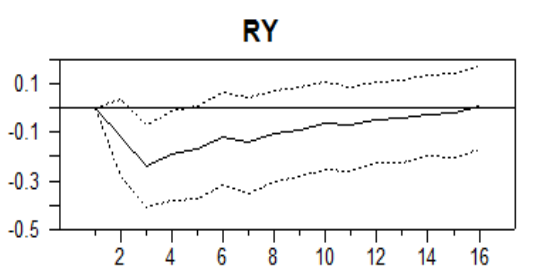

CAR

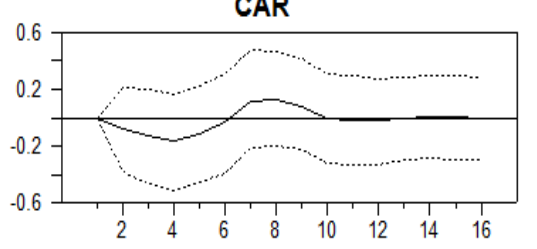

$\mathbf{R}$

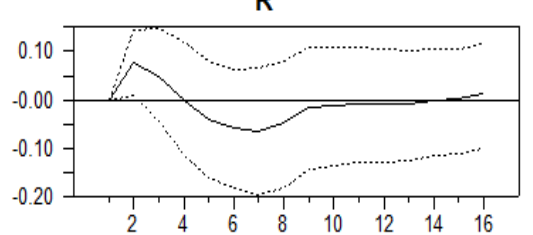

ER

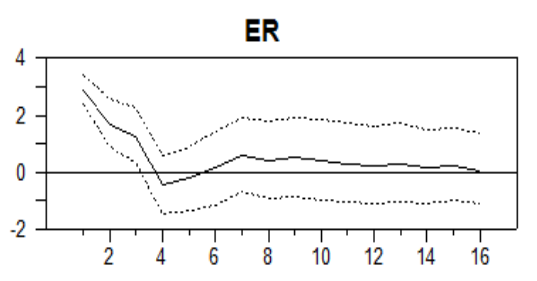

JAPAN

Alternative Identification

Interest Rate
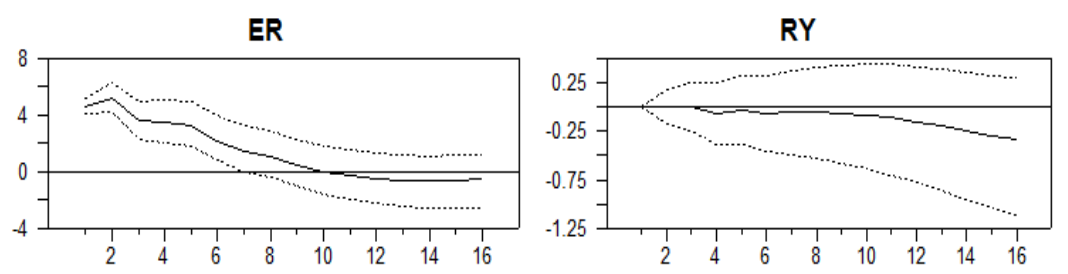

RY

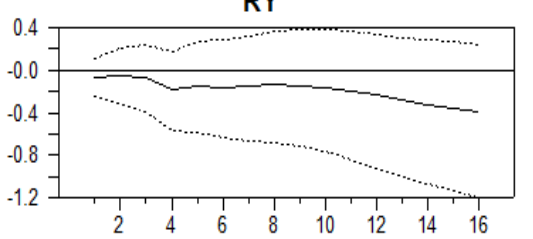

CAR
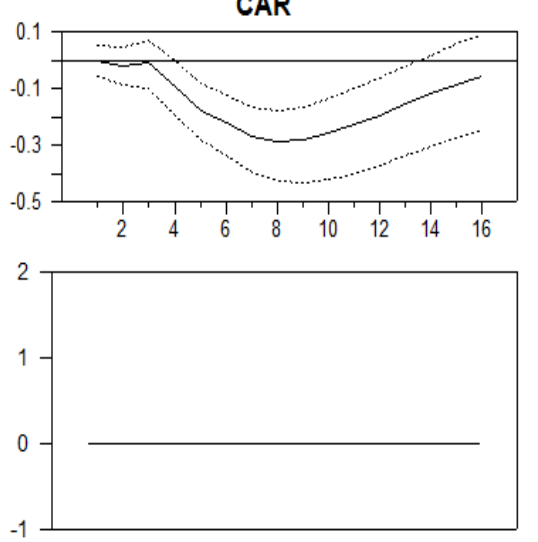

CAR

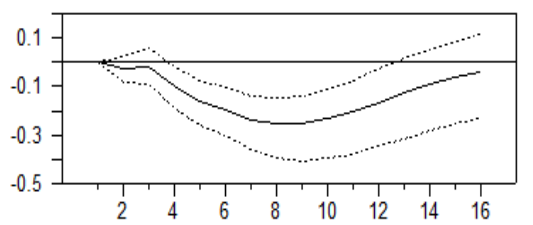

$\mathbf{R}$

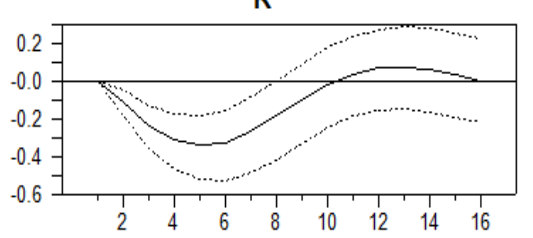

ER

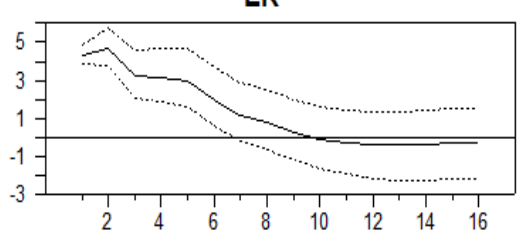


Figure 6. Impulse Responses: Effective Exchange Rate and Real Exchange Rate

CHINA

Effective Exchange Rate

Real Exchange Rate

RY
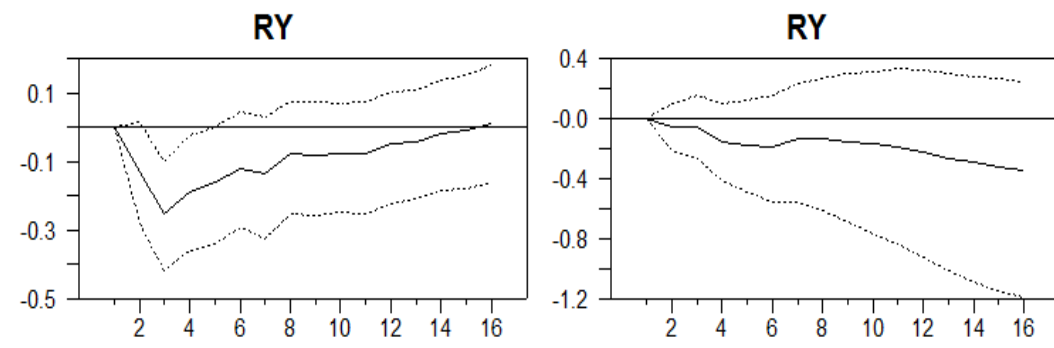

CAR
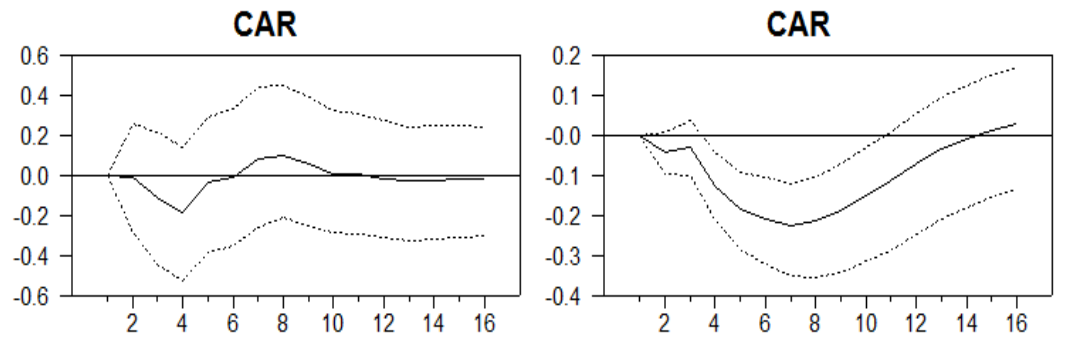

RE

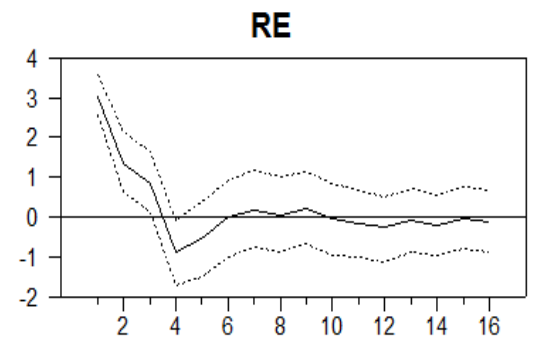

Effective Exchange Rate

JAPAN
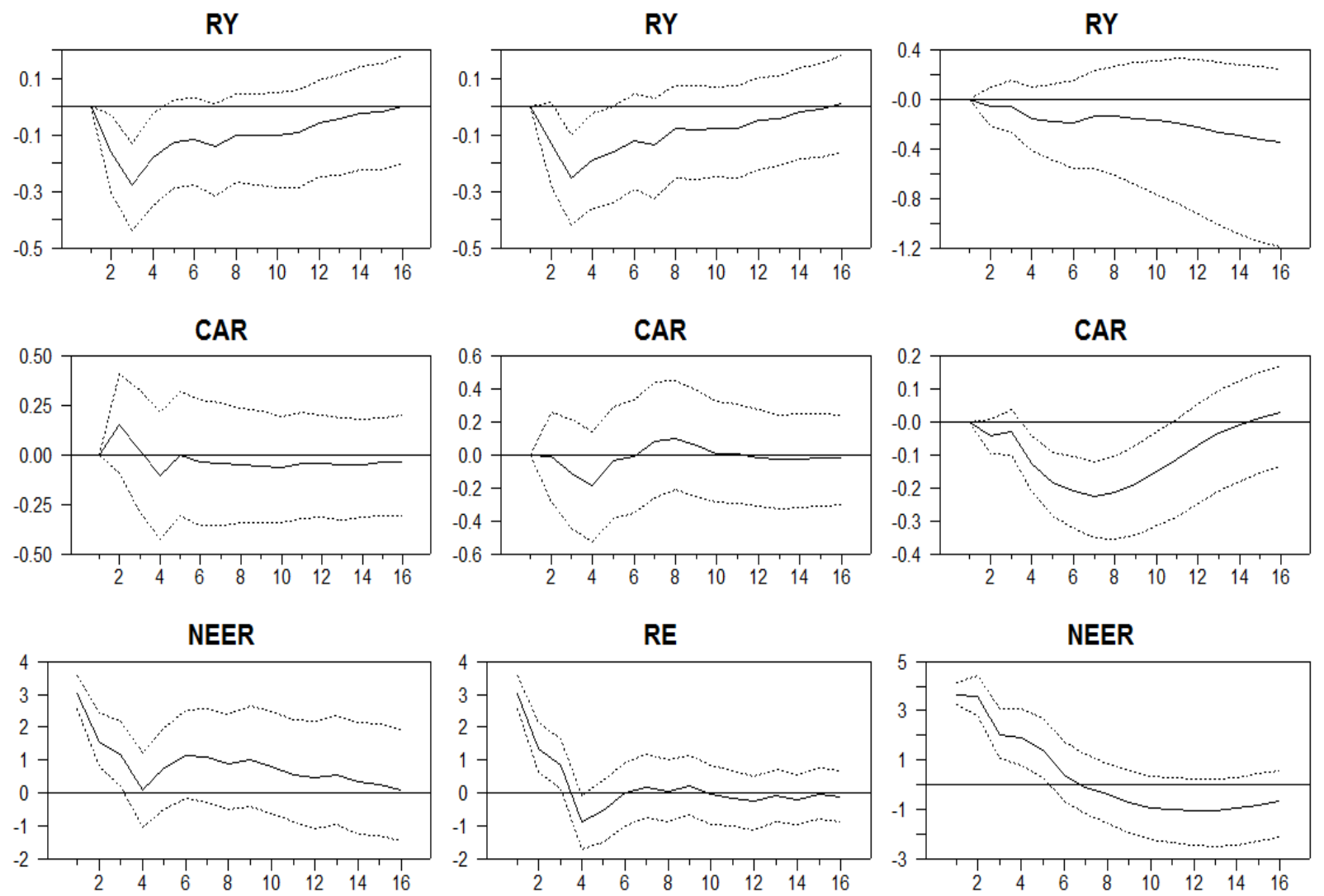
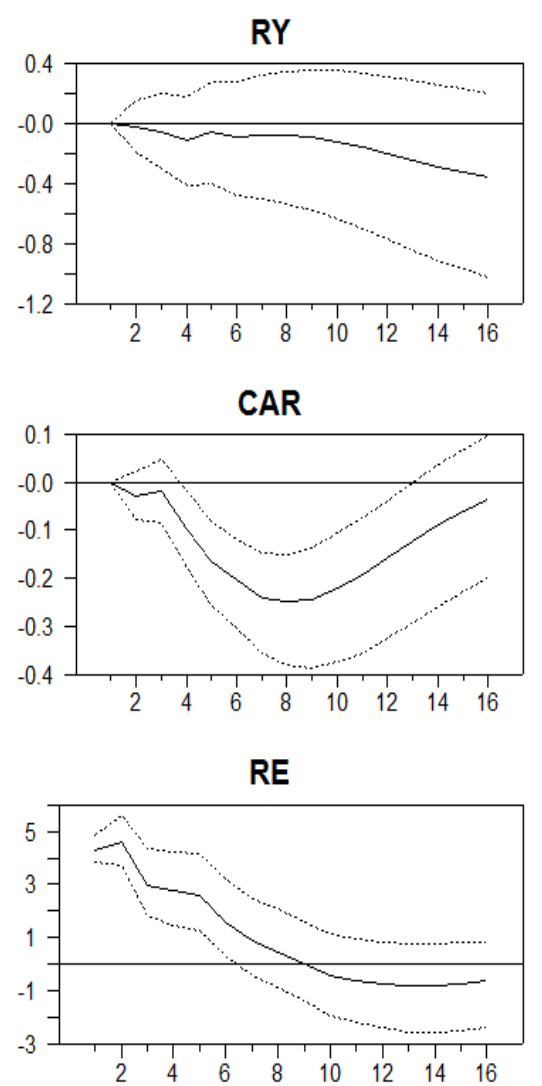
Figure 7. Impulse Responses: Symmetric Model

CHINA
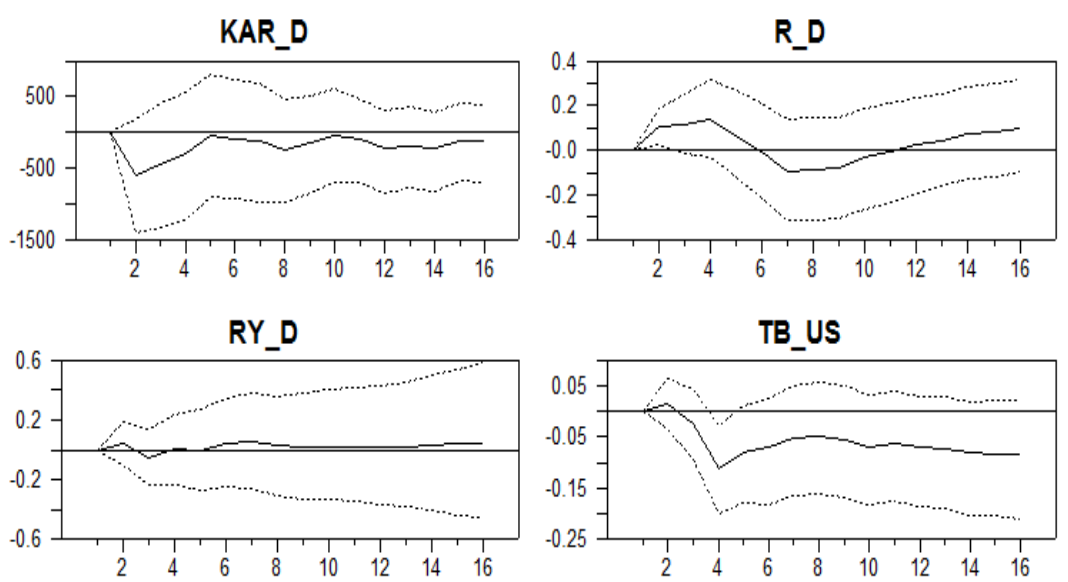

P_D
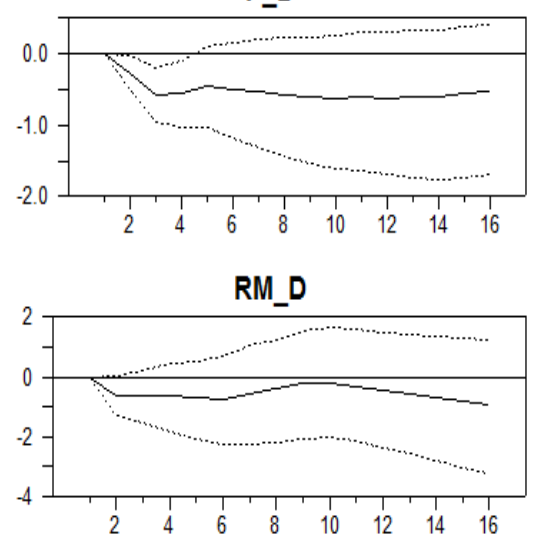

TB_US

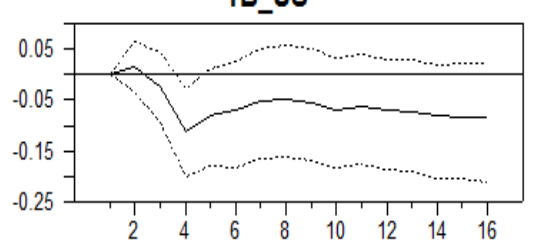

ER
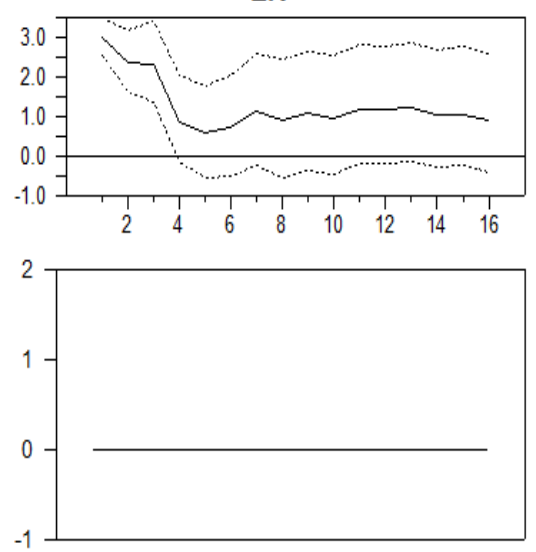

JAPAN
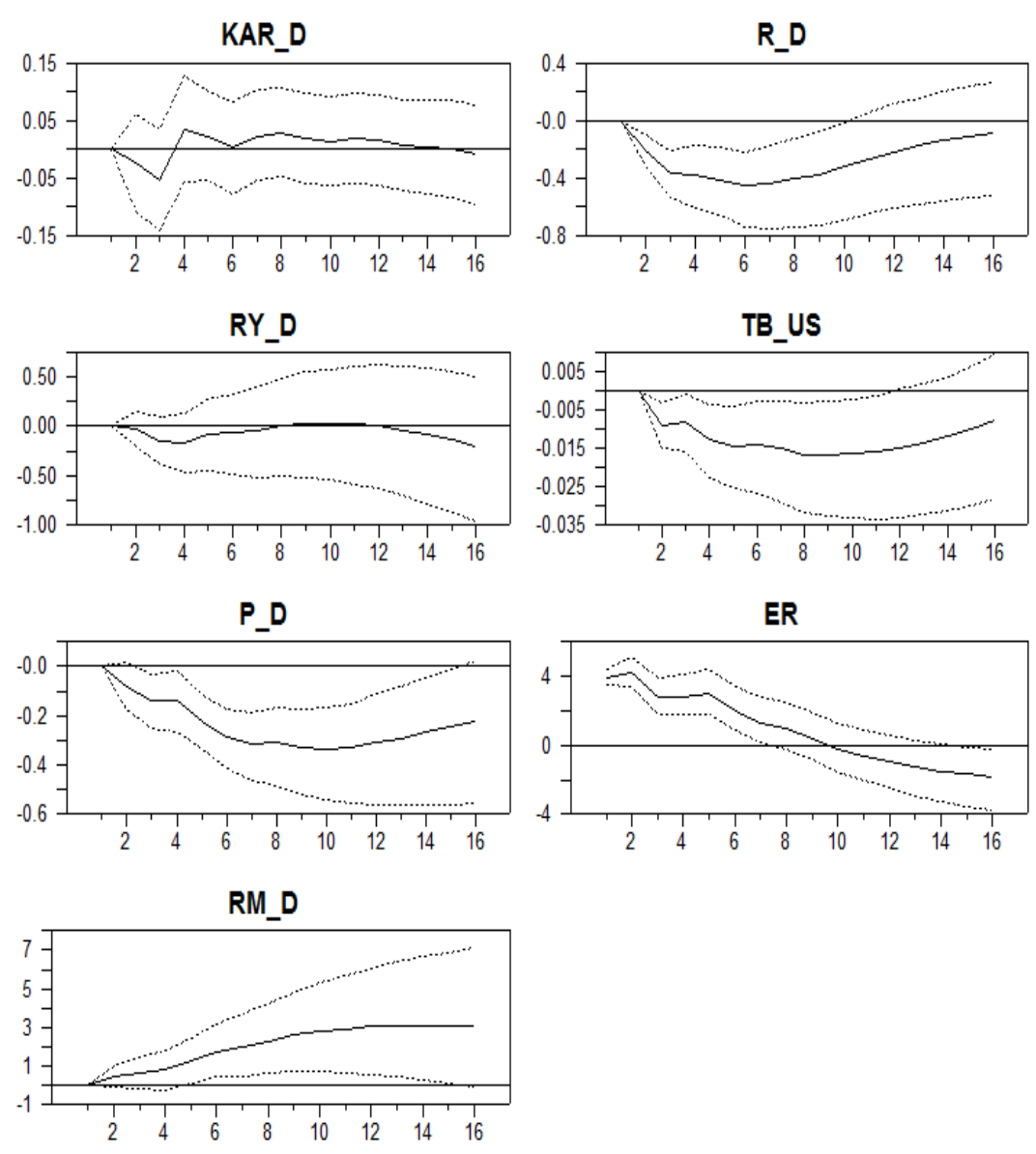
Figure 8. Impulse Responses: China, IFS Data, 1999-2009

Real GDP
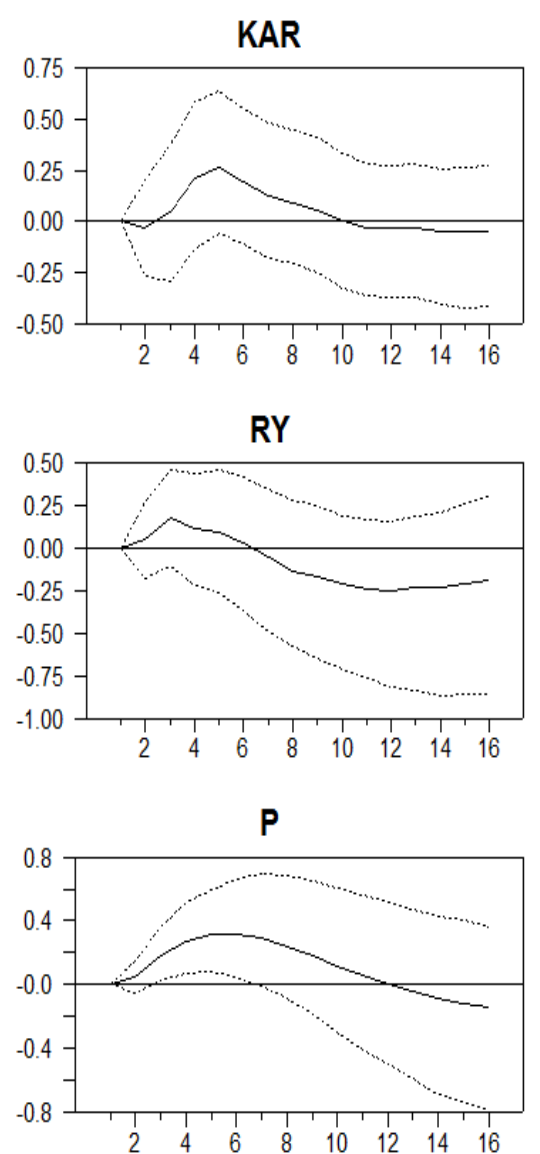

RM

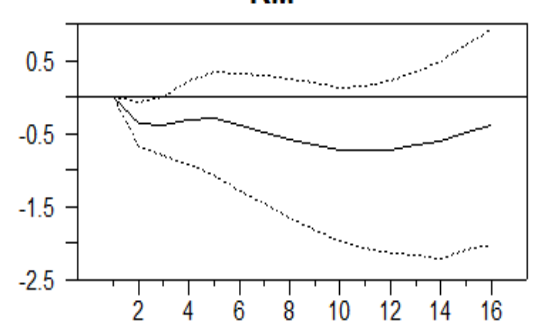

CAR

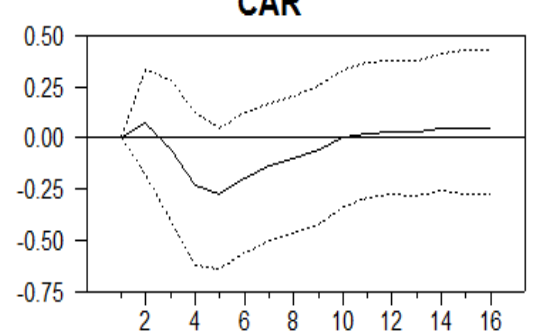

ER

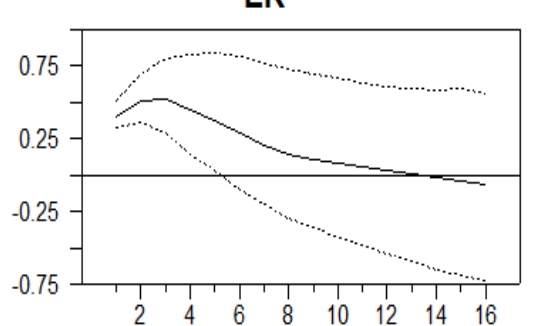

IP
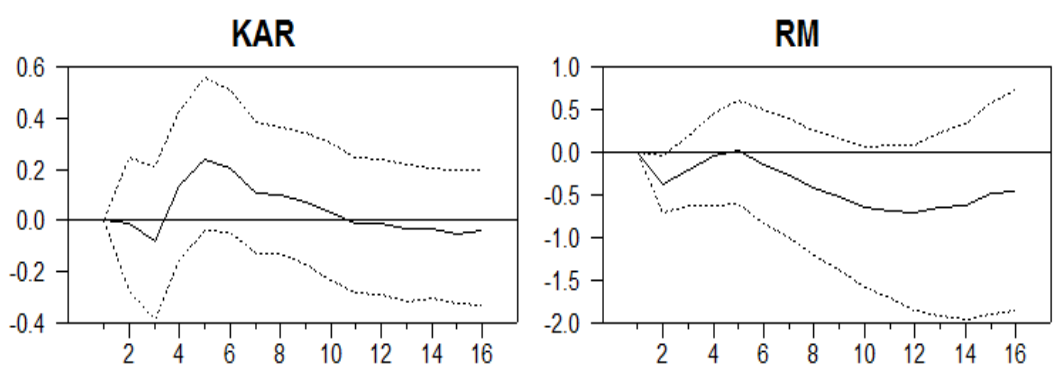

IP
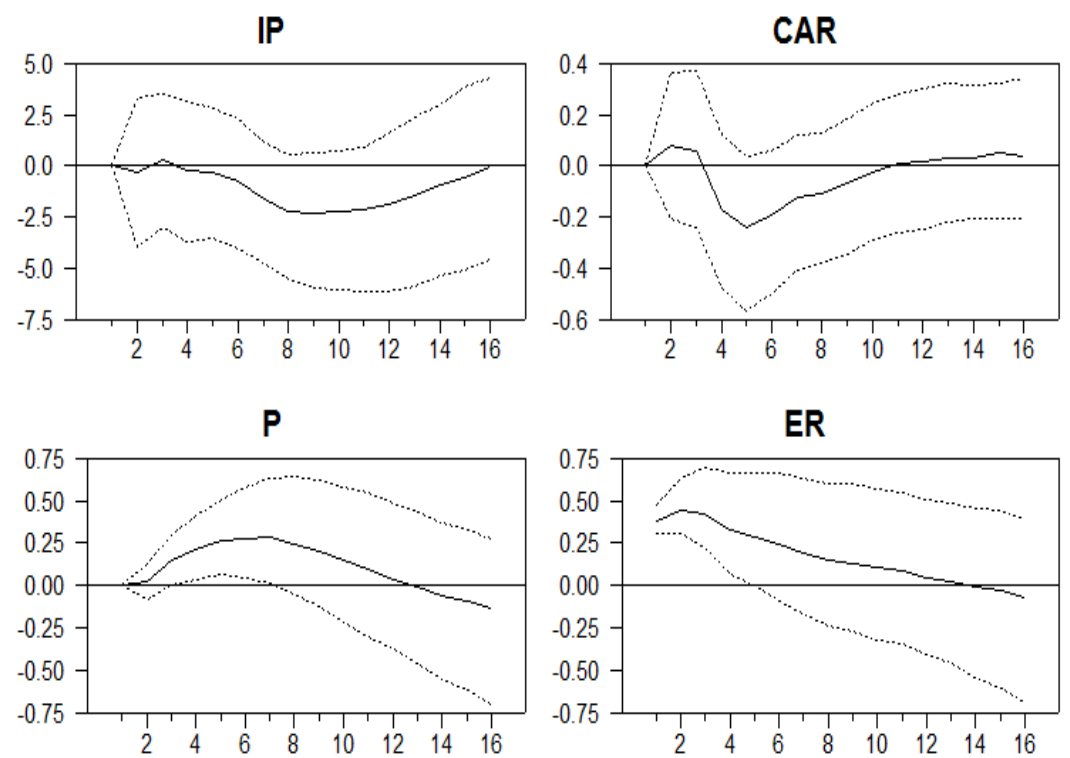

ER

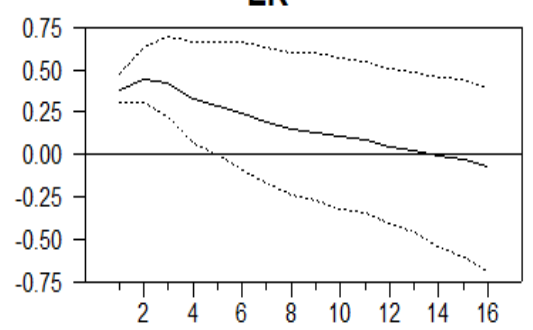

